\title{
Bringing the Environment Back In: Overcoming the Tragedy of the Diffusion of the Commons Metaphor
}

\author{
Benjamin Cashore and Steven Bernstein
}

\begin{abstract}
Contrary to calls for increased relevance, the discipline of political science has had lasting impacts in shaping environmental policy analysis. The ideas and approach advocated by former APSA president Elinor Ostrom, most comprehensively articulated in Governing the Commons, have diffused to shape or reinforce generations of sustainability scholarship. We identify four "ideal type" problem conceptions that are distinguished based on their consistency or inconsistency with Ostrom's inductive approach to problem structure and economic welfare emphasis, and four corresponding schools that reinforce each: commons (Type 1), economic optimization (Type 2), compromise (Type 3), and prioritization (Type 4). Whereas the prioritization school seeks to understand and identify lessons for minimizing the impact of human activity on the natural environment, the diffusion of the commons' metaphor has led political scientists to champion frameworks that bias Type 3,2, and 1 orientations. The latter all rest on moral underpinnings that promote human material interests as their goal, rather than recognizing them as also a primary cause of environmental degradation. A fundamental conceptual reorientation is required if social scientists in general, and political scientists in particular, are to generate an understanding of and identify tools for ameliorating rather than exacerbating today's Type 4 climate change and species extinction crises.
\end{abstract}

The human race is challenged more than ever before to demonstrate our mastery, not over nature but of ourselves. ${ }^{1}$

—Rachel Carson (1962)

The issue in this case-and many others-is how best to limit the use of natural resources so as to ensure their long-term economic viability.

—Elinor Ostrom $(1990,1)$

[The Paris Accord's] pledge-and-review system ... transformed climate diplomacy from past gridlock by creating flexibility ... [A] realistic crash program to cut emissions will blow through 2 degrees; 1.5 degrees is ridiculous. New goals are needed.

\section{—David Victor $(2015,1)$}

$\mu$ growing chorus of political scientists operating from multiple subdisciplines has called for greater attention to problem-relevant research in general

Benjamin Cashore (D) is Li Ka Shing Professor in Public Management in the Lee Kuan Yew School of Public Policy, National University of Singapore (sppbwc@nus.edu.sg).

Steven Bernstein (D) is Distinguished Professor of Global Environmental and Sustainability Governance in the Department of Political Science, University of Toronto (steven.bernstein@utoronto.ca).
(Isaac 2015; Shapiro 2007), and the catastrophic environmental crises of climate change and mass species extinctions in particular (Green 2018; Skocpol 2013; Neville and Hoffmann 2018). In this journal alone, Javeline (2014) has lamented inattention to climate adaptation challenges facing humans, while Falkner (2016) calls for the design of "minilateral" "climate clubs" to reduce "freeriding" under the 2015 Paris Climate Agreement. Economists have made similar appeals (Sachs et al. 2020; Nordhaus 1991).

We offer the opposite conclusion: that political science has profoundly influenced the development of adjudicating frameworks across the social sciences about how to best address environmental problems. Specifically, we argue that the ideas and approach championed by former APSA president Elinor Ostrom in Governing the Commons (1990; hereafter GTC) reinforced and accelerated two trends: turning to the discipline of economics to champion deductive and generalizable theories about politics, policies, and institutions (Shapiro and Green 1994; Simon 1955; Elster 1986); and careful interrogation of a clearly specified sustainability challenge-in Ostrom's case a particular type of "collective action" dilemma known metaphorically as the "tragedy of the commons"-in order to inform and justify inductively generated policy and institutional analysis (Green and Shapiro 1995). Fresh insights from these 
somewhat paradoxical approaches were instrumental in Ostrom winning the Nobel prize in economics.

We argue that GTC's most important contribution to sustainability studies was the way it demonstrated how careful attention to a particular kind of problem can yield innovative solutions. However, its greatest impact was to reinforce the quest for universal analytical frameworks to adjudicate any type of sustainability challenge. This bias occurred directly by those championing economic utility maximization as the overarching goal of policy analysis rather than, as most scholars had assumed in the 1960s and 1970s, as the primary cause of ecological degradation (Meadows et al. 1972). It also occurred indirectly, by those who turned instead to rich literatures in political science on deliberative governance to offer competing universalist approaches also disconnected from problem structure. As a result, today's sustainability-focused political scientists overwhelmingly engage in analysis that shifts attention from understanding how domestic and global environmental policy innovations and institutions might emerge and be designed to avert the negative impacts of humans on the environment (Paehlke 1989; Speth 2004) to assessing whether, given human material interests, it is economically "rational" or feasible to do so. Those political scientists who maintain a focus on problem structure overwhelmingly reinforce GTC's economic utility enhancing concerns, which are the mirror opposite of environmental tragedies.

The implications of our review are profound. Political scientists' quest to explain the limited effectiveness of today's environmental policies that turn to the relative influence of powerful corporations, environmental groups, and marginalized communities, or broader institutional and historical factors that shape class, inequality, and distributional outcomes, need to expand to assess the role of the discipline itself: that is, whether our frameworks and sub-disciplinary debates have, through reinforcing certain metaphors over others, championed conceptions of sustainability that have contributed towards the acceleration of environmental decline. Ironically, Ostrom herself expressed concern about these influences: "[m]any policy prescriptions are themselves no more than metaphors" that "can be harmful," producing outcomes "substantially different from those presumed to be likely" (Ostrom 1990, 22-23).

We elaborate our argument in the following analytical steps. First, we identify four "ideal types" of problems based on their consistency or inconsistency with GTC's emphasis on problem structure and economic utility. Second, we identify and review how four leading schools of sustainability reinforce each type. Third, we show how each school's moral foundations produce distinct "prescriptive projects" that require, for instrumental reasons, expertise in different kinds of research methods and analytical skills. Fourth, we review the contribution of these schools to assess a startling trend: the drift away from treating climate and mass species extinction crises as Type 4 problems. We conclude by offering suggestions for how political science might bring the environment back in.

\section{Four Problem Types and Four Reinforcing Schools}

Types 1 and 2 correspond to GTC's emphasis on economic utility while Types 1 and 4 embrace GTC's careful attention to problem structure (Table 1). Types 2 and 3 champion universal frameworks to adjudicate any challenge. Each of the four sustainability schools' moral underpinnings bias each type in two distinct, but related, ways: how they conceive of sustainability challenges, and, as a result, the empirical data and evidence they target. ${ }^{2}$ These biases are reinforced by very different ways to treat "whack-a-mole" ${ }^{3}$ effects: that is, those cases in which solving one problem makes another worse. The commons, economic optimization, and compromise schools narrow consideration of policy options for ameliorating Type 4 environmental problems to those that are synergistic with Type 1,2, or 3, which are biased toward human material interests.

\section{The Commons School (Type 1 Reinforcing)}

The commons school derives its moral foundations and theoretical roots from concerns about how to understand and resolve "collective action" dilemmas (Olson 1965) in which, owing to absent or weak governance institutions, individuals make "rational" decisions to engage in behaviours that produce suboptimal outcomes (Ostrom 1990, 3). In the classic "prisoner's dilemma" metaphorical example, a thief interrogated in a different cell and unable to coordinate and create compliance mechanisms with an accomplice will make the utility chasing "rational" choice to confess (Nash 1953) because this avoids the risk of an expected higher prison term from remaining silent if the accomplice confessed-even though the thief is aware that that collective silence would have produced lower aggregate prison terms.

The commons school has applied the collective action metaphor in sustainability studies most notably to analyses designed to avoid, or ameliorate, "tragedies of the commons" (Hardin 1968) in which "open access"

\section{Table 1}

The four faces of sustainability

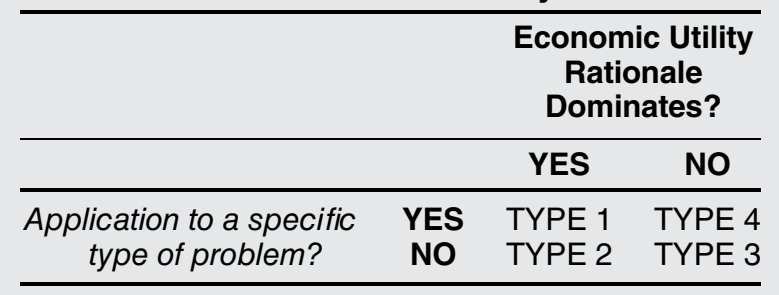


situations lead to depletion of "subtractable" resources: that is, when an individual's use of a specific good reduces the ability of someone else to use it. This school holds that in the absence of coordinating institutions it is entirely "rational" for individuals to participate in overharvesting to realize short-term economic benefits, because, in the absence of collective controls, long-term resource collapse is inevitable. This school's moral duty to avert commons tragedies, including their devastating effects on local communities, was behind Ostrom's exhortation in her presidential address to the American Political Science Association that developing a well-articulated theory of collective action ought to be "the central subject of political science" (Ostrom 1998, 1).

$G T C$ 's contribution to these questions was, through careful attention to the problem structure of commons challenges, the conceptual and empirical discovery thatfor either biophysical reasons (such as the ability of fish to swim long distances) or traditional community practices —excluding access was not a viable solution (Ostrom 1990, 183). This distinction created two ways to classify subtractable resource challenges: excludable "private goods" that characterized most analyses of commons tragedies until GTC and non-excludable "common pool resources" $(C P R)$ on which GTC focused attention. These distinctions also led to utility reinforcing conceptions of "nonsubtractable resources" as either excludable "club goods" or non-excludable "public goods" (table 2).

Ostrom was clear in her beliefs that the tool of privatization, rather than coercive state control, was the most optimal for managing "strictly" private goods (Ostrom 2003, 259; Gibson, McKean, and Ostrom 2000, 7).
GTC's concern was that applying privatization as a solution to non-excludable CPR tragedies could produce even more tragic outcomes than if nothing had been done at all (Ostrom 1990, 13-14) such as the expropriation of communal forests that had historically avoided resource collapse (Bartley et al. 2008; Gibson, McKean, and Ostrom 2000). Instead, GTC posited that local communal governance institutions, including "groups of individuals," rather than "distant" central authorities, were best poised to avoid or reverse many types of unsustainable CPR practices (Ostrom 1990, 21-23, 60-61, 183-185). Somewhat ironically, similar inductive reasoning led the commons school, guided by the "polycentric" metaphor, to advocate for the "scaling up" of its rationalist design principles to ameliorate (economically sub-optimal) "global commons" resource challenges that cut across multiple jurisdictions.

Whack-a-mole. Since GTC's publication, commons school scholars are keenly aware of the need to avoid internal "whack-a-mole" effects that can occur when treating all commons tragedies as excludable. Less attention has been placed on three external whack-a-mole effects that fall outside its moral, theoretical, and conceptual foundations. First, its emphasis on improving the sustainability of a specified resource, such as fish or timber, does not directly address whether the depletion of that good might lead to an economically more optimal outcome-such as forest land use clearing to promote lucrative mineral, extractive, manufacturing, real estate, or tourism activities. Second, while it pays attention to cultural practices that can foster collective long-term economic sustainability in the

\section{Table 2}

\section{GTC's contribution to Type 1 Tragedy of Commons conception of resource goods: Non-excludable common pool resources}

\begin{tabular}{|c|c|c|c|}
\hline & & \multicolumn{2}{|c|}{ Excludability } \\
\hline & & \multicolumn{2}{|c|}{ Is the renewable resource in question easily "excludable"? } \\
\hline & & Yes & No \\
\hline \multirow{2}{*}{$\begin{array}{c}\text { Subtractable? } \\
\text { (Does using it reduce it?) }\end{array}$} & Yes & $\begin{array}{r}\text { Private goods } \\
\text { (e.g., timber) }\end{array}$ & $\begin{array}{l}\text { Common pool resource goods } \\
\text { (e.g., fish stocks) }\end{array}$ \\
\hline & No & $\begin{array}{c}\text { Club goods } \\
\text { (e.g., toll roads, } \\
\text { professional associations) }\end{array}$ & $\begin{array}{l}\text { Public goods } \\
\text { (e.g., air) }\end{array}$ \\
\hline \multicolumn{4}{|c|}{$\begin{array}{l}\text { Note: Examples of goods in each cell are illustrative. Commons and sustainability scholars continue to differ on whether to treat trees, } \\
\text { fish, and ecosystems as "private goods," "common pool resources," and, in some cases, as "public" or "club" goods. These debates can } \\
\text { be traced back, in part, to different ways in which categories and corresponding solutions are constructed (Young 2007, 3-4). For } \\
\text { example, following GTC, some view institutions, depending on their design, as causing or solving a particular resource depletion } \\
\text { tragedy (i.e., they constitute the "independent" variable). However, others view institutional arrangements, not simply biophysical } \\
\text { features, as playing a role in making excludability difficult (i.e., they constitute part of the "dependent" variable). It follows that if a } \\
\text { researcher deems institutions to have played a role in making excludability difficult, it is equally plausible, in contrast to GTC's } \\
\text { inferences, to consider designing institutional innovations to make exclusion possible. This ambivalence in treating excludability as } \\
\text { fixed and hence a "common pool resource", or as changeable, and hence a "private good," is reflected in GTC's conclusions that } \\
\text { resource quotas that exclude access are useful for managing, rather than converting, CPRs. } \\
\text { Source: Adapted from V. and E. Ostrom } 1972 \text { and Gibson, Mckean, and Ostrom 2000. }\end{array}$} \\
\hline
\end{tabular}


absence of formal institutions (Ostrom 1990, 149, 166; Sethi and Somanathan 1996), it did not formally incorporate into its model "suboptimal" historical cultural traditions that are degraded by an emphasis on economic utility (Buck 1998). Third, as we will detail, ecosystems are almost always degraded in some way by successful Type 1 solutions and institutions.

\section{The Economic Optimization School (Type 2 Reinforcing)}

Whereas the commons school champions economic utility to address a clearly specified collective action problem, the economic optimization school advances the moral belief, drawing on welfare economics, that the ability to solve any kind of problem is conditional upon finding policy solutions that enhance aggregate economic utility for society as a whole (Kenny 2011; Sen 1979; Luke 2009).

Within sustainability studies, this school's moral framework provides the rationale for most post-World War II development agencies, most notably the World Bank, and many specialized UN agencies, such as the United Nations Food and Agricultural Organization (FAO), as well as the creation of forestry, agriculture, and resource schools in Europe and North America that followed utilitarian principles to achieve "the greatest good for the greatest number in the long run" (Pinchot 1987). It also underpins the field of environmental economics, which advances the causal belief that the rational and feasible way to address environmental challenges is to convert them into economic values (Stavins 1995; Sachs et al. 2020; Thomas and Chindarkar 2019). These moral frames, in turn, are reinforced through micro level metaphors including "externalities" that treats environmental degradation as economically suboptimal and "payment for ecosystem services" by those who believe that valuing nature economically will provide ancillary environmental benefits (Sell et al. 2007). This morality is also behind the "polluter pays" metaphor (OECD 1972) which holds that firms can choose to make economic payments to offset, rather than stop, environmentally degrading behaviour.

This school also includes neo-utilitarian international relations sustainability scholarship on cooperation and rational institutional design (e.g., Keohane and Victor 2016; Ovodenko and Keohane 2012) whose analytical frameworks do not directly incorporate, nor are they derived from, the structural features of the environmental problem at hand, but on efficient institutions and utility enhancement. Scholars from this community created the "Oslo-Potsdam" approach to environmental effectiveness, which measures policy options against their "collectively optimal" utility enhancing human benefits (Hovi, Sprinz, and Underdal 2003). For these reasons its application can result in an international regime being assessed as "effective" even when the ecological problem at hand continues to worsen (Kütting 2000; Young 2003a). In the most extreme cases, some treat Type 2 human satisfying outcomes not only as synergistic but as synonymous with Type 4 environmental concerns (e.g., Lomborg 2001). Although GTC was initially justified based on a Type 1 problem conception, its rationalist project meant that the research program, and that of those who built upon it, were sympathetic to the economic optimization school's moral philosophy (Ostrom 2005).

Whack-a-mole. This school's internal approach to whack-amole effects by assessing society-wide economic welfareenhancing or -reducing impacts of a proposed policy option, leads them to and requires incorporating as many moles as possible - a process adherents refer to as "internalizing externalities." However, this approach can create several external moles. At a broad level, its economic growth-biased policy solutions have played a role in fostering industrialization processes that have contributed to the homogenization of previously diverse local cultures while severely stressing the earth's environmental "carrying capacity." In addition, its emphasis on converting environmental values into economic utility comparators undermines reflexive considerations of a morality promoting the intrinsic value of ecological systems qua ecological systems.

\section{The Compromise School (Type 3 Reinforcing)}

The compromise school draws its moral foundations from a rich literature devoted to assessing how democracy, pluralism, legitimacy, trust, and authority might advance policymaking at multiple scales (Dahl 1961; Rosenbluth and Shapiro 2018; Bodansky 1999; Habermas 1973; March and Olsen 1998; Scharpf 1999). Its adherents tend to be united around the promotion of "human dignity" rather than economic utility (Farr, Hacker, and Kazee 2006).

Within sustainability studies, attention has been placed on assessing how inclusionary processes and deliberative spaces might foster meaningful involvement of disempowered environmental and social interests and values (Dryzek 1990; Hoberg 1992; Pinkerton 1993; Aklin and Mildenberger 2017). Its moral philosophy is reinforced by significant evidence that, if well designed, the participatory processes can enhance legitimacy, trust, and authority to meaningfully affect policy outcomes (Barry and Eckersley 2005).

This school has been prominent at the international level since the 1987 Brundtland Commission (WCED 1987), which famously called for "meeting the needs of the current generation without compromising the ability of future generations to meet their own needs." In doing so, it directly confronted the economic optimization school's belief that future economic impacts ought to be 
discounted and that social and environmental outcomes could be assessed on their economic values. It also engaged a conversation with the prioritization school by incorporating concerns about the impacts of humans on the natural environment (Wang 2004).

Whack-a-mole. The internal approach to moles of balancing economic, environmental and social goals, risks several external moles. First, stakeholder engagement at domestic and global levels often produce "incremental" approaches that rarely veer far from the status quo, in part owing to the role of powerful economic interests (Coglianese 1997). Mitchell and Carpenter $(2019,5)$ found, for example, that $\mathrm{CO}_{2}$-emitting business interests have acted as "veto-players" in international climate deliberations when they deem "the costs of climate action as excessive." Second, the application of deliberative governance principles can result in disastrous consequences for the problem at hand. For example, Type 3 multistakeholder engagement in the Newfoundland cod fishery resulted in a compromise decision to allow harvesting at levels higher than what scientists found were required for species to reproduce (Berrill 1997). The result was that the Type 1 fisheries economy collapsed, further degrading the Type 4 marine ecology from what commercial fishing had already caused.

\section{The Prioritization School (Type 4 Reinforcing)}

The prioritization school advances a moral philosophy in which analysts must distinguish, and give priority to, "first order" principles and problems (see, for example, Rawls 1971). The classic example concerns the eradication of slavery in which the very application of economic optimization or compromise approaches that turn attention to assessing whether or to what extent slavery might be allowed undermines the problem conception and outcome itself: that is, that no one, for any reason, ought to be allowed to own another human being. This school incorporates three central analytical tasks: overcoming Types 2 and 3 and "commensurability biases" to rank or prioritize problems; developing-just like GTC-inductively generated solutions based on the key features of the problem at hand; and engaging in lexical or sequential policy analysis in which addressing lower-ranked problems are limited to solutions that do not undermine higher-ranked problems.

Within sustainability studies, the prioritization school targets attention to the attributes of key social and environmental problems that usually result from, or are exacerbated by, those very policies that embrace Types 3, 2, and 1 conceptions (Sinden, Kysar, and Driesen 2009; Zeckhauser and Schaefer 1968; Ackerman and Heinzerling 2004; Taylor 1992; Meadows et al. 1972). This school's heyday was during the "first wave of environmentalism" in the 1960s and 1970s that was sparked, in part, by Rachel Carson's (1962) warning that "[T]he human race is challenged more than ever before to demonstrate our mastery, not over nature but of ourselves." Tribe (1972, 95) famously reinforced this ethical frame by arguing- in direct confrontation with the economic optimization school's morality-that "[it does not] seem peculiar to insist ... that a lower limit be established on especially cruel treatment of animals, whatever the economic gains this cruelty brings to persons in general" (Tribe 1972, 96). Tribe argued that leading contenders for Type 4 status included "vulnerable or "fragile" problems, especially "ecological balance, unspoiled wilderness, species diversity, and the like ... [that are] ... intrinsically incommensurable, in at least some of their salient dimensions, with the human satisfactions" (Tribe 1972, 96).

Just like the slavery case, the prioritization school's approach is usually required to achieve "fit for purpose" environmental solutions (Tribe 1972, 95, 96, 99). This is because failure to grant the climate and species extinction crises as Type 4 challenges risks adopting policy and institutional solutions that are inconsistent with, or gloss over, ecological knowledge: that is, producing Newfoundland-esque outcomes for the world's most important ecological challenges (IPCC 2018; IPBES 2019).

Whack-a-mole. The prioritization school recognizes that its sequentialist morality can create "collateral damage" moles. Its ranking of environmental problems as highest on the pecking order has been criticized as "elitist" (Farrell 2020) that ignores the plight of the world's most poor and vulnerable populations, including indigenous and rural communities. However, prioritization school scholars respond that granting lexical ordering to the environment can, indeed, subsequently ameliorate social and cultural challenges (Clapp and Dauvergne 2005), just not in the way envisioned by economic optimization or compromise schools that in so many cases result in "lose/lose" undermining outcomes for ecosystems and local cultural traditions (McAfee 1999).

While proponents of the prioritization school within sustainability studies have thought carefully about how to handle external moles, the school has largely failed to explicitly assess the problem of internal moles: that is, how to conceive of and research the range of Type 4 environmental problems with which to grant lexical status. Intriguingly, Ostrom called for such thinking, arguing that while biological and ecological systems were different from those covered in GTC, they, too, could be enhanced by similar inductive attention to the features of the problem at hand (Ostrom 1990, 25-26).

Attention to this task reveals four implicit approaches to prioritizing environmental challenges (table 3). The holistic approach is motivated by scientific evidence that, in some cases, the structure and function of an entire ecosystem is required to maintain the viability of an individual species. The end point for lexical ordering means that both 
Table 3

Four approaches to the tragedy of Type 4 species extinctions

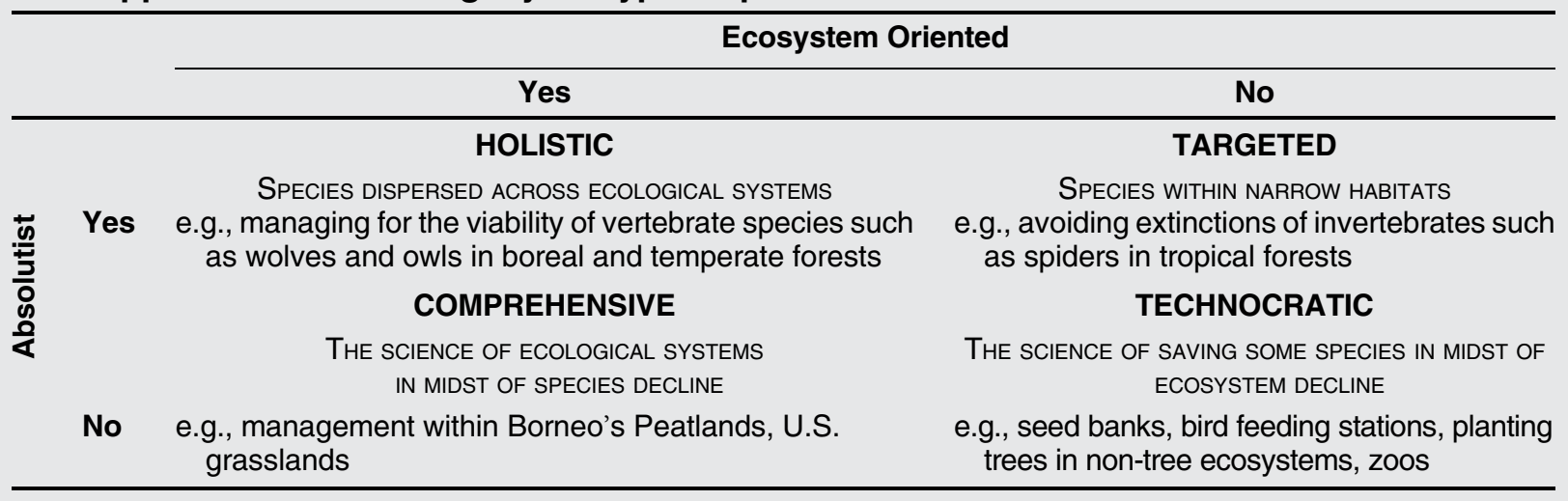

the species and eco-system must be granted first order status if each of them is to be effectively addressed. In these cases, data are collected to assess what amount of extractive activity, including eco-friendly logging practices, might be permitted without compromising either individual species or the broader ecological systems (Lindenmayer and Franklin 2003). Intriguingly, GTC appeared to favour this approach when advocating for the identification of relevant proxy species with which to guide inductive policy and institutional solutions for advancing ecosystem sustainability (Ostrom 1990, 25-26). In contrast, the targeted approach draws on scientific evidence-especially but not exclusively from tropical and subtropical climates-that some species, including non-charismatic invertebrates, live on such small parcels of land that any act of extraction will almost certainly result in their extinction (Grove 2002; Wijedasa et al. 2017; Nair 2007).

The comprehensive approach targets maintaining ecosystem structure and function in the face of some degree of "inevitable" species loss given human disruptive practices. The overarching concern is to identify the "limits" or "carrying capacity" of natural systems. This approach is behind the Paris Accord's $1.5^{\circ} \mathrm{C}$ goal-which, drawing in the IPCC's scientific review, explicitly accepts some degree of ecological degradation caused by greenhouse gases, but at a level that is expected to avoid catastrophic changes in ecosystem structure and function.

The technocratic approach is motivated by the scientific evidence concerning species decline given inevitable ecosystem degradation. This approach has resulted in policy innovations from the creation of seed banks to store genetic material from degraded or destroyed ecosystems, the strategic placing of feeding sites for migratory birds, and even the creation of zoos and wildlife conservation areas. It also captures the motivations of those political and policy scientists who, working with engineers and businesses, focus attention on developing low-carbon technologies that are not derived based on, or are deemed unlikely to meet, the $1.5 / 2^{\circ} \mathrm{C}$ imperative.

These distinctions help qualify contradictory findings and arguments in sustainability studies and science. First, scholarly declarations of utility and environment synergies ignore or bypass empirical evidence from the targeted approach because any human-satisfying activity will result in extinction. Second, the holistic approach narrows consideration of synergies to those utility-enhancing activities that, following scientific evidence, are deemed not likely to threaten the viability of ecosystems and their species. Third, while the technocratic orientation has the most synergies across problem types, its acceptance of an ecologically degraded world is hardly the outcome that most Type 4 environmental sustainability scholars would find celebratory.

\section{Four Prescriptive Projects}

The moral and analytical foundations that shape each school's adjudicating frameworks (Table 4) result in four prescriptive projects-successful implementation of which requires turning to and gaining expertise in distinct sub-disciplines and research methods (Table 5).

\section{The Commons School}

Design principles. GTC was clear that "better policies" (Ostrom 1990, 29) for averting or avoiding depleting water, fish, timber, and other goods that contribute to human food and resource production systems required "arranging for the supply of new institutions" (Ostrom 1990, 14) that must be placed on "how best to limit the use of natural resources so as to ensure their long-term economic viability" (Ostrom 1990, 1). Ostrom offered that getting the utility enhancing "institutions right" requires identifying and granting "user rights," reducing "free-riding" risks, and "commitment problems." She cautioned that successful efforts in "monitoring 


\section{Table 4}

\section{Four sustainability schools}

\begin{tabular}{|c|c|c|c|}
\hline & & \multicolumn{2}{|c|}{ Economic Utility Rationale Dominates } \\
\hline & & YES & NO \\
\hline \multirow{4}{*}{$\begin{array}{l}\text { Application to a } \\
\text { specific type of } \\
\text { problem structure? }\end{array}$} & & $\begin{array}{l}\text { THE COMMONS SCHOOL } \\
\text { (TYPE } 1 \text { REINFORCING) }\end{array}$ & $\begin{array}{l}\text { THE PRIORTIZATION SCHOOL } \\
\text { (TYPE } 4 \text { REINFORCING) }\end{array}$ \\
\hline & $\begin{array}{c}\text { YES } \\
\text { (contingent) } \\
\text { Generalizable } \\
\text { only to the } \\
\text { problem at hand }\end{array}$ & $\begin{array}{l}\text { - Problem specification } \\
\text { - resource depletion } \\
\text { "tragedies of the } \\
\text { commons" } \\
\text { - e.g., harvesting } \\
\text { resources such as fish } \\
\text { and timber beyond the } \\
\text { reproduction yield rate } \\
\text { - subclass includes } \\
\text { "common pool } \\
\text { resources" (CPRs) } \\
\text { - Problem orientation } \\
\text { - producing collectively } \\
\text { optimal institutions for } \\
\text { the resource in ques- } \\
\text { tion }\end{array}$ & $\begin{array}{l}\text { - Problem specification } \\
\text { - irreversible environmental } \\
\text { tragedies } \\
\text { - e.g., species extinctions, } \\
\text { catastrophic ecological } \\
\text { effects of climate change } \\
\text { - subclass includes "super } \\
\text { wicked" problems } \\
\text { - Problem orientation } \\
\text { - utility/economic motiv- } \\
\text { ations are the cause, not } \\
\text { the solution }\end{array}$ \\
\hline & \multirow[b]{2}{*}{$\begin{array}{c}\text { NO } \\
\text { (universal) } \\
\text { Generalizable to } \\
\text { all problems }\end{array}$} & \multirow{2}{*}{$\begin{array}{l}\text { THE ECONOMIC } \\
\text { OPTIMIZATION SCHOOL } \\
\text { (TYPE } 2 \text { REINFORCING) } \\
\text { - Problem specification } \\
\text { - all } \\
\text { - Problem orientation } \\
\text { - aggregate economic } \\
\text { utility }\end{array}$} & $\begin{array}{l}\text { THE COMPROMISE SCHOOL } \\
\text { (TYPE } 3 \text { REINFORCING) }\end{array}$ \\
\hline & & & $\begin{array}{l}\text { - Problem specification } \\
\text { - all } \\
\text { - Problem orientation } \\
\text { - utility shares stage with, } \\
\text { rather than subsumes } \\
\text { underneath, social, cul- } \\
\text { tural, environmental goals }\end{array}$ \\
\hline
\end{tabular}

individual compliance with sets of rules" (Ostrom 1990, 27) would be "a difficult, time-consuming, conflict-invoking process" (Ostrom 1990, 14).

Methods. The search for theories to inform particular Type 1 challenges-in GTC's case, CPR tragedies-helps explain the commons school's embrace of game theoretic models and quantitative methods required to build them. Qualitative ethnographic methods play a supporting role in so far as their insights help improve model building (Brondizio, Ostrom, and Young 2009; Araral 2014, 12; Andersson, Evans, and Richards 2009).

\section{The Economic-Optimization School}

Design principles. The dominant prescriptive project advocated by the economic optimization school is to engage in some type of "cost-benefit" analysis (Adler and Posner 2009; Arrow et al. 1996) in which disparate social, environmental, cultural and economic goals are given comparable economic utility values. This approach, which underpins the U.S. Environmental Protection Agency's policy to value each statistical human life at $\$ 9.47$ million USD (Environmental Protection Agency 2020) involves modelling across a range of outcomes, as well as discounting future economic impacts, to identify the "best" or most "rational" policy options. Internal debates-including whether policies must be avoided that increase inequality (Kaldor 1939) whether operationalized as widening gaps in relative gains (Piketty 2015) or Pareto losses (Awan 2013) - reinforce the school's overarching emphasis on utility enhancing orientations by narrowing measurements of inequality to economic outcomes.

Methods. The economic optimization school requires application of quantitative and modelling techniques, including agent-based modelling and econometrics, to project future outcomes, and the production of quantitative surveys of consumers and the public's "willingness to pay" so that concerns about species extinctions, wilderness, and the catastrophic ecological effects of climate change can be converted into economic values (Turner et al. 2003).

\section{The Compromise School}

Design principles. The compromise school's prescriptive project turns to applying some type of "multi-goal" policy analysis (Weimer and Vining 1992) and stakeholder 


\begin{tabular}{|c|c|c|c|c|}
\hline & $\begin{array}{c}\text { Prescriptive } \\
\text { Project }\end{array}$ & Methodologies & Disciplinary Roots & Management Skills \\
\hline $\begin{array}{c}\text { THE COMMONS } \\
\text { SCHOOL } \\
\text { (Type } 1 \\
\text { reinforcing) }\end{array}$ & $\begin{array}{l}\text { DEVELOP } \\
\text { COLLECTIVELY } \\
\text { OPTIMAL } \\
\text { INSTITUTIONS }\end{array}$ & $\begin{array}{l}\text { Quantitative for } \\
\text { developing } \\
\text { generalized } \\
\text { principles, } \\
\text { supported by } \\
\text { ethnographic } \\
\text { case studies }\end{array}$ & $\begin{array}{l}\text { Economics, rational } \\
\text { choice political } \\
\text { science, } \\
\text { anthropology } \\
\text { (supporting role) }\end{array}$ & $\begin{array}{l}\text { Ability to apply large } \mathrm{N} \text { data } \\
\text { analysis, ability to apply } \\
\text { universal design } \\
\text { principles to local } \\
\text { contexts through } \\
\text { ethnographic } \\
\text { techniques }\end{array}$ \\
\hline $\begin{array}{l}\text { THE ECONOMIC } \\
\text { OPTIMIZATION } \\
\text { SCHOOL } \\
\text { (Type 2 } \\
\text { reinforcing) }\end{array}$ & $\begin{array}{l}\text { ENHANCE } \\
\text { ECONOMIC } \\
\text { WELFARE }\end{array}$ & $\begin{array}{l}\text { Quantitative } \\
\text { through } \\
\text { econometrics } \\
\text { modeling, game } \\
\text { theory }\end{array}$ & $\begin{array}{l}\text { Economics, public } \\
\text { choice political } \\
\text { science (rational } \\
\text { choice, public } \\
\text { choice) }\end{array}$ & $\begin{array}{l}\text { Ability to incorporate a } \\
\text { range of behaviors into } \\
\text { economic values to } \\
\text { determine whether } \\
\text { problem is solvable }\end{array}$ \\
\hline $\begin{array}{l}\text { THE } \\
\text { COMPROMISE } \\
\text { SCHOOL } \\
\text { (Type 3 } \\
\text { reinforcing) }\end{array}$ & $\begin{array}{l}\text { MULTI-GOAL } \\
\text { POLICY } \\
\text { ANALYSIS AND/ } \\
\text { OR MULTI- } \\
\text { STAKEHOLDER } \\
\text { DISPUTE } \\
\text { RESOLUTION }\end{array}$ & $\begin{array}{l}\text { Mixed: diverse } \\
\text { range of } \\
\text { quantitative and } \\
\text { qualitative } \\
\text { analysis }\end{array}$ & $\begin{array}{l}\text { Political Science } \\
\text { (legitimacy, state- } \\
\text { society interaction), } \\
\text { sociology, } \\
\text { psychology, } \\
\text { anthropology, } \\
\text { economics }\end{array}$ & $\begin{array}{l}\text { Ability to foster agreement } \\
\text { among stakeholders or } \\
\text { find intervention that } \\
\text { balance competing } \\
\text { interests and goals. } \\
\text { Ability to foster trust and } \\
\text { legitimacy among } \\
\text { participants }\end{array}$ \\
\hline $\begin{array}{c}\text { THE } \\
\text { PRIORTIZATION } \\
\text { SCHOOL } \\
\text { (Type } 4 \\
\text { reinforcing) }\end{array}$ & $\begin{array}{l}\text { UNLEASH PATH } \\
\text { DEPENDENT } \\
\text { POLICY } \\
\text { TRIGGERS }\end{array}$ & $\begin{array}{l}\text { Historical, } \\
\text { qualitative, } \\
\text { process tracing, } \\
\text { reflexive }\end{array}$ & $\begin{array}{l}\text { Political Science } \\
\text { (historical } \\
\text { institutionalism), } \\
\text { historical sociology, } \\
\text { history, some } \\
\text { strands of } \\
\text { geography }\end{array}$ & $\begin{array}{l}\text { Ability to identify, and } \\
\text { unleash, path } \\
\text { dependent "critical } \\
\text { junctures"; manage } \\
\text { means-oriented } \\
\text { stakeholder learning } \\
\text { processes }\end{array}$ \\
\hline
\end{tabular}

deliberations to achieve consensus or "dispute resolution." They specifically incorporate research on the ways in which different interests or values might be incorporated to avoid Type 2 drift (Raymond and DeNardis 2015; Clémençon 2012).

Methods. Decisions over methods turn to "multidisciplinary" or "interdisciplinary" knowledge generation owing to causal and moral beliefs that integrating a diversity of perspectives will yield the most legitimate and effective policy responses (Nilsson and Weitz 2019; Saez and Requena 2007; Clark and Wallace 2011). Special attention has been placed on applying comparative qualitative case studies, reinforced by quantitative methods, to understand how environment and development "advocacy coalitions” might reach policy consensus (Sabatier 1988).

\section{The Prioritization School}

Design principles. The prioritization school is motivated by data produced from the biological, natural, and physical sciences about the startling decline of species and ecosystems (Kütting 2000). It places careful attention on what scientific evidence indicates is required to avoid or reverse the effects of human activity in general, and commodification of nature in particular, on terrestrial, marine, and atmospheric ecological systems. This task requires, for example, understanding and disentangling scientific evidence about the shorter "shelf life" of land use-caused climate change emissions that also threatens biodiversity from longer-term emissions caused by carbon-dependent industrialization processes. Members of this school are keenly aware of the need to avoid conflating environmental and economic outcomes, such as measures of decreases and increases in "forest cover," since the former often results from permanent decline of Type 4 primary forest ecosystems, while the latter includes temporary and permanent increases in Type 1 forest management (figure 1).

Methods. Prioritization scholars recognize that Type 4 environmental problems such as the species extinctions and climate crises are overwhelmed in political and policy processes that emphasize Types 3, 2, and 1 short-term or material interests (Lockwood et al. 2017; Levin et al. 2012). They therefore devote much methodological attention to identifying "critical juncture" policy levers with 


\section{Figure 1}

\section{Global forest expansion and deforestation, 1990-2020 (million hectares per year)}

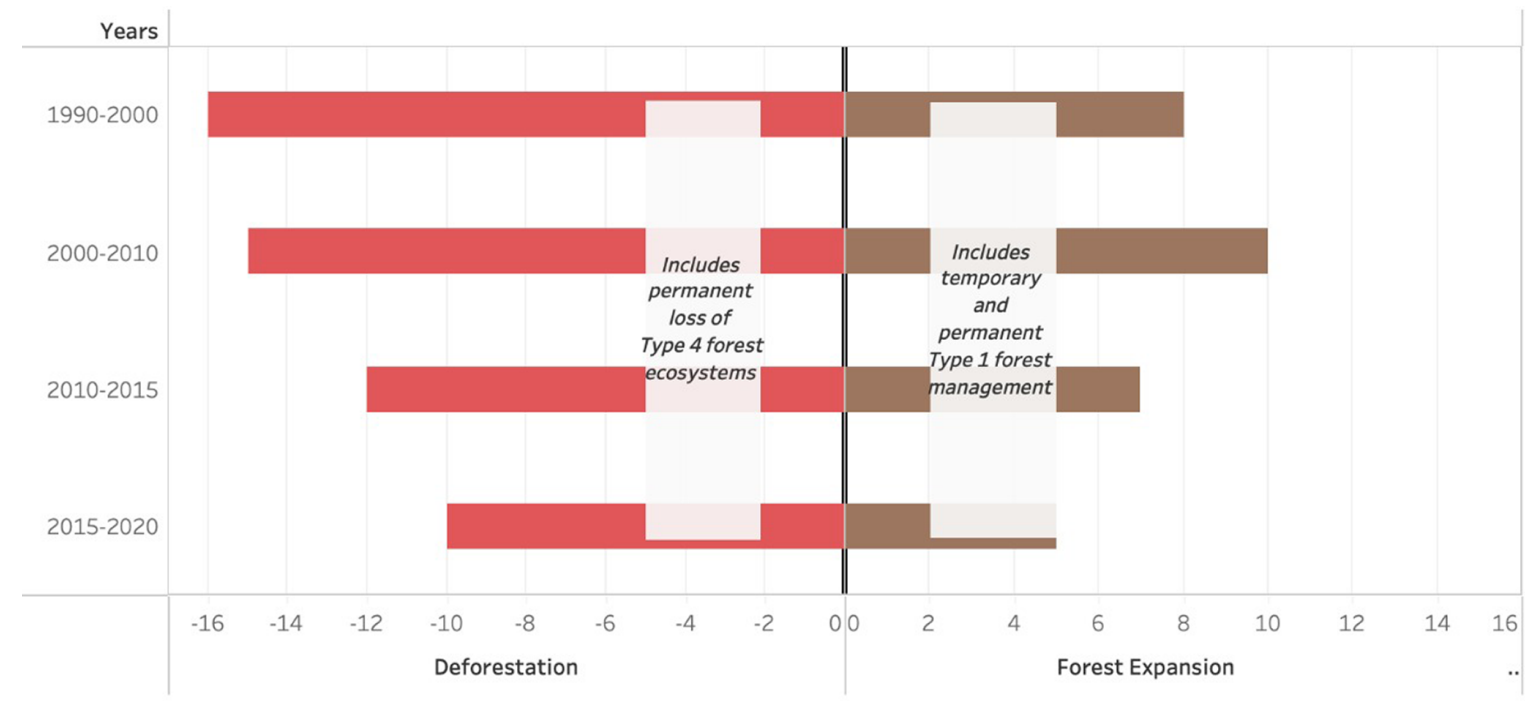

Source: FAO stat

which to create "path dependent" transformative pathways (Jordan and Moore 2020). In contrast to the economic optimization school's negative view of path dependency as utility undermining (North 1990), prioritization scholars assess how such processes can, and do, change policy outcomes, values, and feasibility calculations (Lockwood et al. 2017; Pierson 1993).

This school recognizes that critical junctures are not only triggered by societal and stakeholder conflict (Skocpol 2013) $)^{4}$ but through the creation of innovative "policy mixes" (Howlett 2019). The latter turns analytic attention not only to the goals and tools of policy, but to the causal impact of choices over calibrations that dictate resources and approaches to compliance, and policy settings that specify behavioural requirements (Hall 1993). This approach was integral to the multi-faceted design of Germany's successful and widely diffused "feed-in-tariffs" policy aimed at accelerating uptake of low carbon energy sources (Meckling 2019). Its unfolding effects over a decade and a half not only reduced the price of solar panels owing to increasing economies of scale, but also caused changes to behavioural norms and beliefs that dramatically altered political feasibility and willingness to pay calculations (Schmid, Sewerin, and Schmidt 2019).

For these reasons, the prioritization school places a premium on developing and applying sophisticated qualitative methods necessary for producing reflexive thinking for deliberating over the thousands of policy design possibilities, as well as for choosing specific mixes based on their "plausible causal logics" for generating multiple-step trajectories capable of ameliorating the problem at hand. Specific techniques include "applied forward reasoning" (Bernstein et al. 2000) and "process tracing" associated with historical institutionalist methodologies.

\section{Drifting Away from Type 4: Political Science's Contribution to Sustainability Studies}

There is widespread recognition that the economic optimization school has helped advance the design of Type 2 development policies around the world, and that these have contributed to exponential economic growth since the 1970s that has lifted hundreds of millions of people out of poverty (figure 2). There are also widespread concerns among all four schools about several unintended whack-a-mole effects including increases in greenhouse gases (figure 3), the decline of ecological systems exemplified by loss of tropical primary forests (figure 4) and the resulting decline in species abundance (figure 5) (McCauley 2006). While political science has provided several foundational approaches that turn to global social structures and mechanisms of class reproduction that influence societal and government conceptions of problems (Lukes 1974; Herman and Chomsky 1988; Lindblom 1977; Wendt 1987; Bachrach and Baratz 1962), less attention has been placed on our own culpability in causing these moles.

\section{Domestic Policy Responses to Species Extinction Threats}

Type 4. A generation ago the prioritization school played a central role in researching and drawing conclusions about 
Figure 2

World economic growth and poverty alleviation

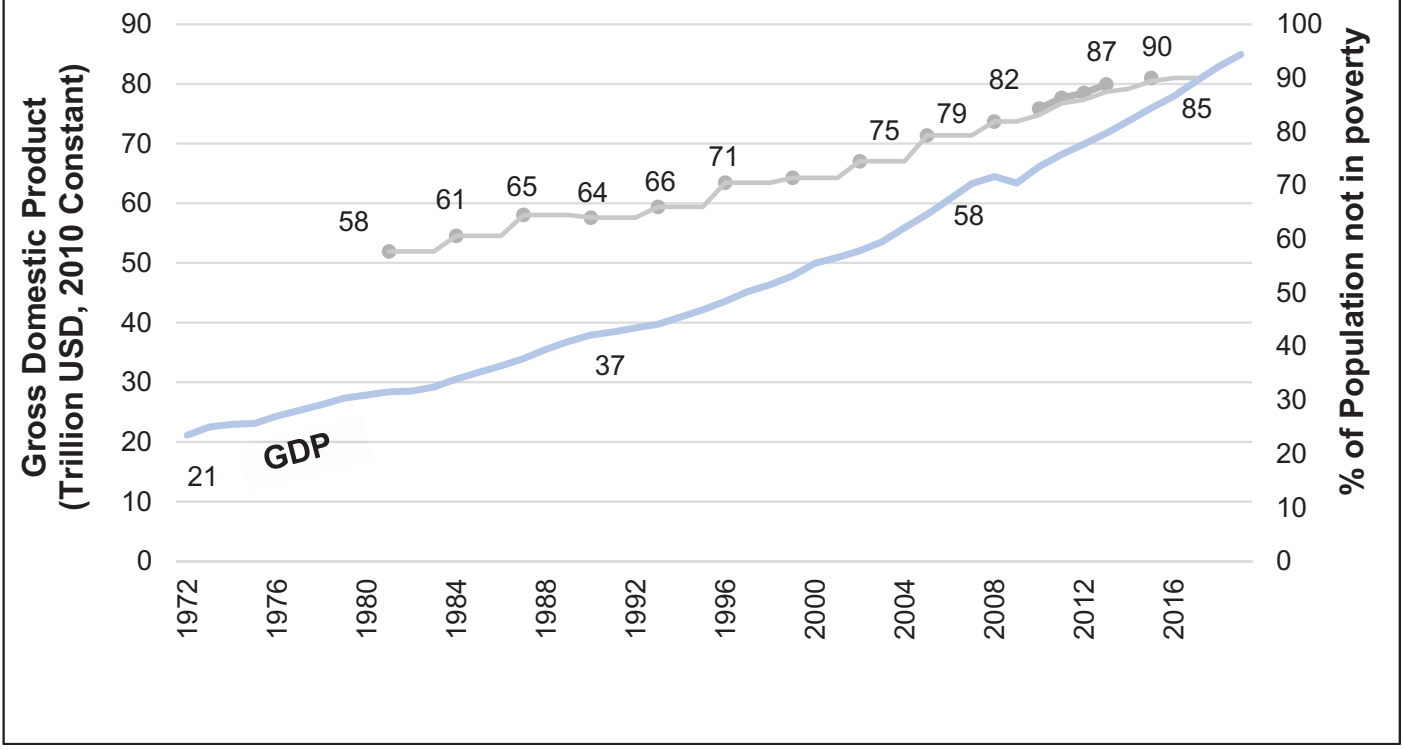

Source: World Bank 2020

Figure 3

CO2 emissions and global temperatures

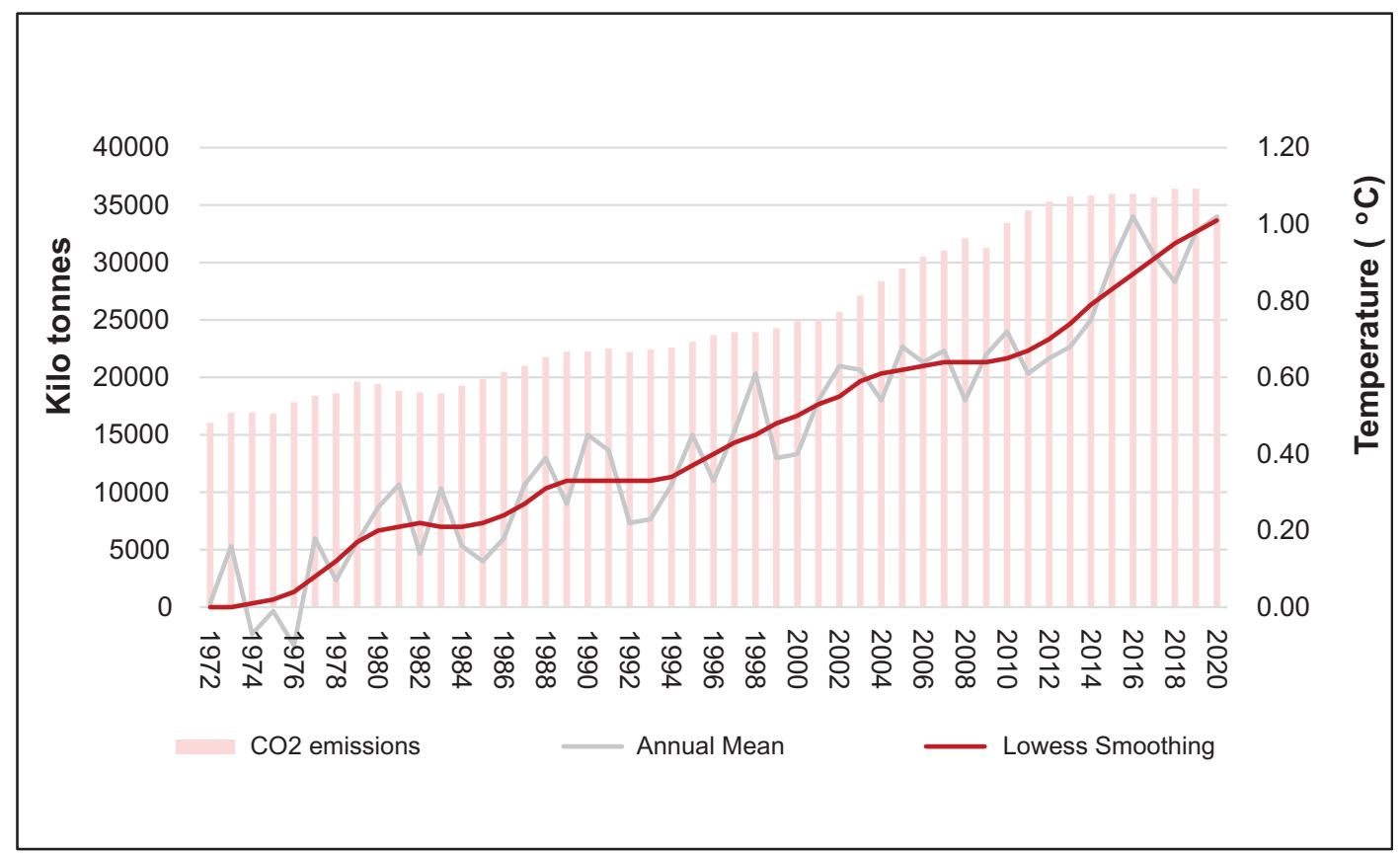

Source: World Bank 2020; NASA 2020 


\section{Figure 4}

\section{Tropical (Type 4) primary forest loss, 2002-2020 (millions of hectares)}

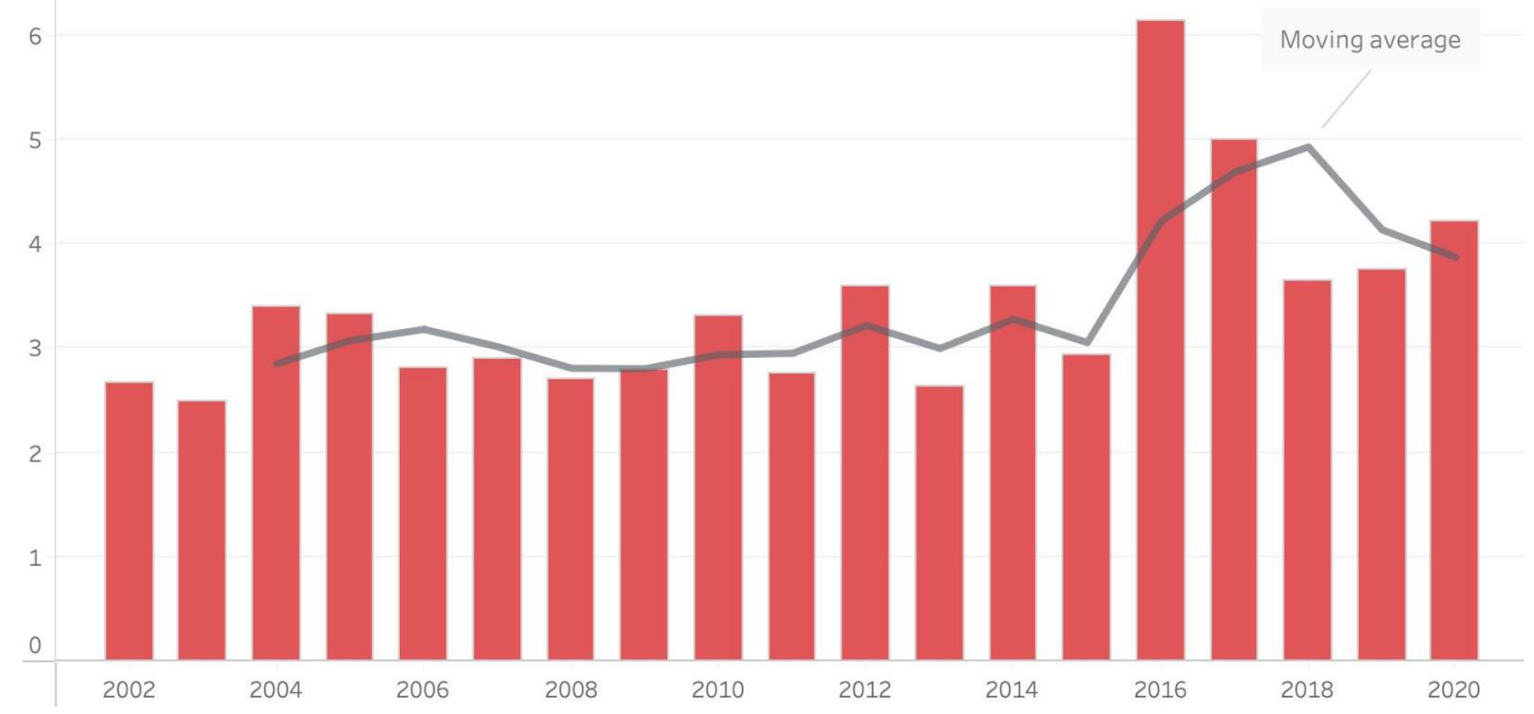

Source: WRI 2020

Figure 5

Species abundance (1970s baseline)

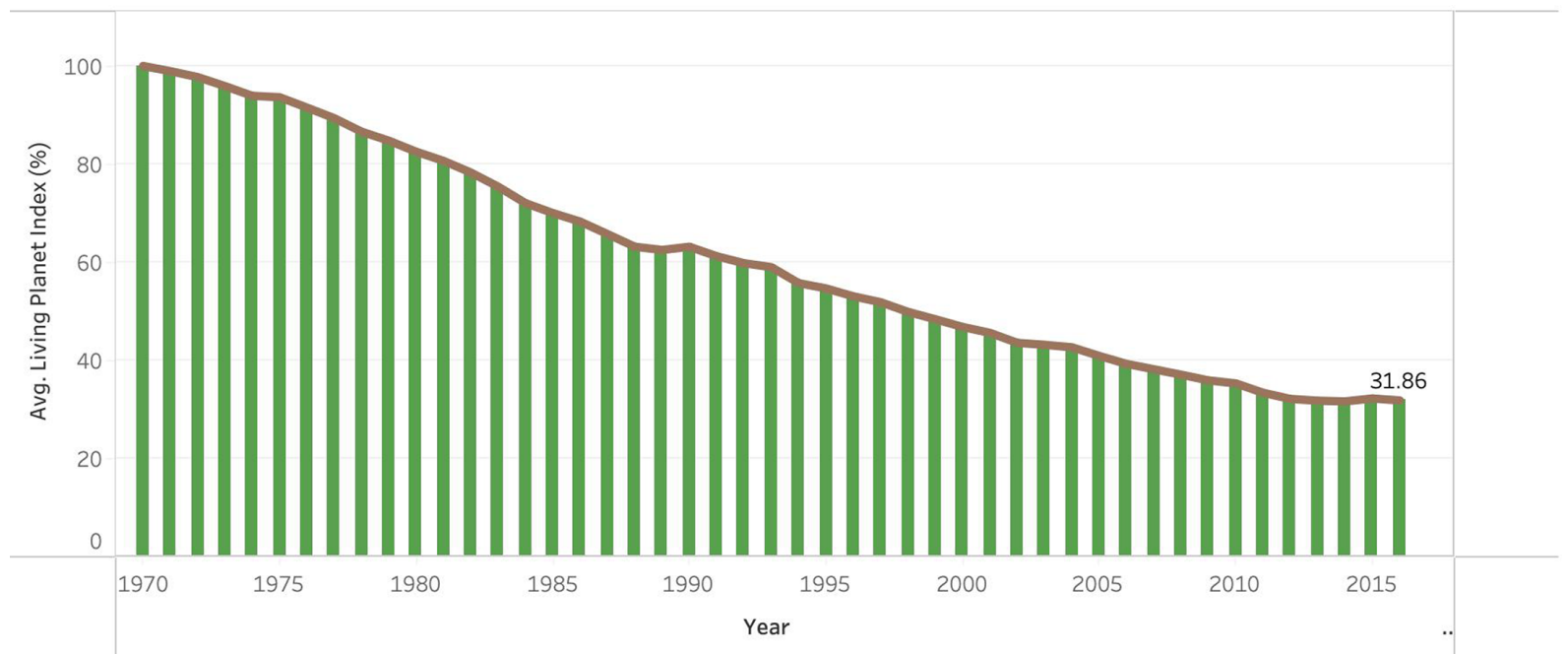

Source: Living Planet Index 2016; Our World in Data 2020

the conditions through which environmental tragedies might be averted. Its contribution to Type 4 species extinction threats resulted in several explanatory and applied conclusions-almost all of which confront GTC's design principles for CPR challenges. First, transnational political economy scholars found that economic interests promoted conceptions of sustainability that narrowed approaches to conservation to those consistent with economic optimization (Dauvergne 2001; Gale 1998; Levy and Egan 1998; Curran and Trigg 2006) and sought to incorporate concerns about the economic prosperity of forest- and resource-dependent communities into their Type 1 and 2 projects, even if doing so resulted in increasing extinction threats (Voigt et al. 2018).

Second, specific wording of policy objectives, settings, and calibrations can create path-dependent Type 4 critical 
junctures. For example, political science research found that the conservation of old growth forests and restriction of logging practices in the U.S. Pacific Northwest was owing to the requirement that a lead agency develop a management plan to maintain the "viability" of a species listed as threatened or endangered (Cashore and Howlett 2007). In this case, massive shifts toward Type 4 holistic ecosystem management (table 3) and away from Type 1 logging practices on national forest lands (figure 6) followed scientific evidence that the "Northern Spotted Owl" required old growth forests to survive (Kohm 1991; Franklin 1994; Spies et al. 2018).

Third-and in contrast to the commons school's emphasis on decentralization and "subsidiarity" (e.g., Wright et al. 2016; Somanathan, Prabhakar, and Mehta 2009)—national governments tend to give the most voice to environmental values, followed by state or provincial jurisdictions in federal systems, with the least voice within local governance systems denoted by strong economic dependence on resource extraction (Allin 1982; Bishop, Phillips, and Warren 1995; Leader-Williams, Harrison, and Green 1990; Dunlap 1992).

Members of the prioritization school found that one reason for these trends is that citizens who live in urban areas are more likely to express higher levels of Type 4 environmental values (Czech and Krausman 1999;
Inglehart 1995), while rural and forest-dependent communities and commodity interests tended to view nature as providing utility enhancing benefits for humans (Paddle 2002; Laurance and Useche 2009) while holding negative views of endangered wild animals whose own foraging and predation undermine their Type 1 economic livelihoods (Vittersø, Kaltenborn, and Bjerke 1998; Skogen 2015). The result is that environmental voices are often marginalized, or disempowered, when community governance initiatives are given the authority to manage specific resource challenges. These dynamics are illustrated in the case of the spotted owl, where president Bill Clinton successfully deployed vice president $\mathrm{Al}$ Gore to fend off the local congressional delegation efforts-strongly supported by forestdependent communities_aimed at seeking relief from Type 4 statutory requirements (Yaffee 1994; Sher and Stahl 1990; Gorte 1993; Lange 1993).

Fourth, large scale national public land ownershiprather than privatization or local governance preferred by $G T C$ - created the conditions through which lexical priority was granted to the owl (Giaari 1994). In contrast, logging on private land that applied Type 1, 2, or 3 conceptions, resulted in Newfoundland-esque responses that were inconsistent with the scientific evidence of owl conservation (figure 6).

\section{Figure 6}

\section{Effects of Dominant Problem Types on Logging in the U.S. Pacific Northwest, 1970-2018}

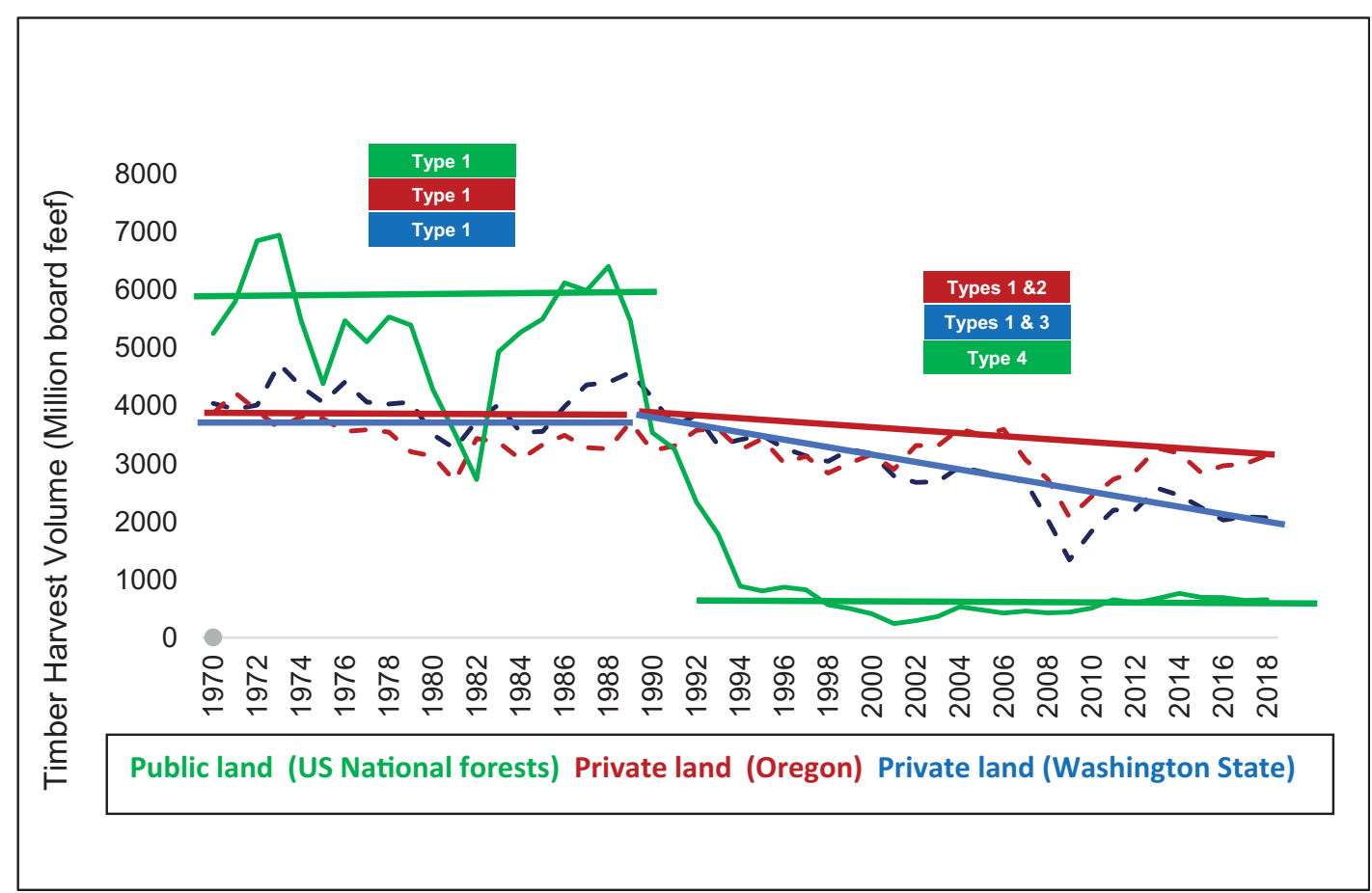

Source: U.S. Department of Agriculture, Forest Service, Pacific Northwest Research Station 2020 
Drift. What is critical for our analysis is that sustainability scholars wittingly and unwittingly played key roles in reinforcing the explicit project of powerful interests, including those from extractive industries, in fostering drift away from Type 4 conceptions dominant in the 1970s, 1980s, and 1990s. In the owl case, the most immediate source of drift came from leading economic optimization school scholars who criticized ecosystem management as "irrational" because the decline in employment and incomes would cause significant Type 2 economic welfare reducing whack-a-mole effects (Lippke et al. 1990; Perez-Garcia 1993; Rawls and Laband 2004). These conclusions would be drawn on by several business interests who, worried that the owl case might set a precedent, funded Type 1 and 3 dialogues with environmental NGOs and forest-dependent communities (Forests Dialogue 2018), and Type 2 "free market" resource and environment research think tanks strongly critical of (economic welfare reducing) environmental regulations (Simpson 2005).

A much more subtle but arguably even more powerful contribution to this drift came from compromise school scholars within the United States and globally who sought to understand better the "science" of conflict avoidance and consensus (see, for example, Halbert and Lee 1990; Wondolleck 1988; Crowfoot and Wondolleck 1991; Bacow and Wheeler 1984; Coglianese 1997; Brach et al. 2002; Koontz and Thomas 2006). This conceptual turn would lead scholarly claims that their scientific research found that sustainability solutions required compromise be reached among disparate groups (Jacobsen and Linnell 2016; Bryant and Jackson 1999; Baker et al. 2009). Practitioners and policy officials would draw on these conclusions to justify as "scientific" their quest to elaborate the "foundations" (Starik 1995) of "multiple-use" land management (Shands 1988) that treat ecological systems as part of, rather than degraded by, human systems (Schmitz 2018; Reed et al. 2019; Matson, Clark, and Andersson 2016). The U.S. National Academy of Sciences subsequently institutionalized this Type 3 drift by defining "sustainability science" as "the interactions between natural and social systems, and with how those interactions affect the challenge of sustainability: meeting the needs of present and future generations while substantially reducing poverty and conserving the planet's life support systems" (Kates 2011, 19449).

\section{Global Environmental Climate Governance}

Type 4. A generation ago the prioritization school was dominant within international relations (Markham 1996; Najam and Sagar 1998). Its adherents documented the role of global capitalism and associated consumption in both causing these challenges (Meadows et al. 1972; Conca, Princen, and Maniates 2001) but also supporting
Type 3, 2, and 1 policy responses (Bernstein 2001; Humphreys 2006). This school also reinforced GTC's emphasis on problem structure by turning to relevant proxies from the scientific community, highlighted by the $1.5 / 2^{\circ} \mathrm{C}$ imperative, for interrogating whether policy and institutional responses were consistent with the problem at hand (Young 2003b).

Drift. The championing of the "sustainable development" metaphor would subtly but powerfully crowd out the prioritization school by narrowing assessments of environmental problem solving to those synergistic with human material interests (Carpenter et al. 2009; Bernstein 2001) most recently formalized under the Sustainable Development Goals (SDGs) (Bowen et al. 2017; Clémençon 2021). This, in turn, has reinforced drift within the United Nations Environment Programme (UNEP), which was created in 1972 as the lead international organization to deliberate over and orchestrate approaches to ameliorating Type 4 ecological crises (Ivanova 2021). Following fifty years of frustrations over ecological decline, UNEP has reinvented itself subtly, but powerfully, now filling its ranks with economic optimization scholars and celebrating Type 2 conceptions of nature (UN Environment 2020b, 2020a).

This drift helps explain why, despite a half-century of empirical evidence of ongoing whack-a-mole effects between ecological challenges and human material interests (Nilsson and Weitz 2019; Independent Group of Scientists 2019) (figures 1-6), and the metaphorical spotted owl example, UN-sanctioned social science assessments have proclaimed with "high confidence" (IPCC 2018, sec. 2.5.3) that synergies among environmental, social, and economic goals "far exceeds the number of trade-offs" and that any whack-a-mole effects can be averted through careful design and management of "transition oriented portfolios" (IPCC 2018, 33). They have also declared-in direct conflict with Type 4 research on species extinctions but consistent with the Type 1 commons and Type 3 compromise school's moral beliefsthat there was "high agreement," "high confidence," and "medium evidence" that local community governance is central to advancing these synergies.

A closer read reveals that these conclusions pivot away from drawing on evidence of Type 4 climate change or species extinctions to researching instead the ability of humans to adapt to, rather than avert, these ecological crises (IPCC 2018, sec. 2.5.3). Tragically, these conclusions have been drawn on to advocate for "scaling up" Type 3 local collaborative processes to meaningfully reverse Type 4 human impacts on species extinctions and the climate crisis (Díaz-Reviriego, Turnhout, and Beck 2019; Barkin and Shambaugh 1999; Dietz, Ostrom, and Stern 2003; Andersson and Ostrom 2008; Andersson, Evans, and Richards 2009). 
International climate negotiations. The effects of this drift are so strong that the majority of social scientists still conclude-despite mounting empirical evidence that these Type 2 reinforcing policies have failed to achieve Type 4 outcomes (Green 2021) - that attention to economically optimal outcomes are synergistic with addressing the climate crisis as an ecological problem (Tobin 2020).

This belief in synergies also appears to explain the gap between the 2015 Paris Climate Agreement's Type 4 rhetoric that the scientific evidence requires limiting temperature increases no longer to $2^{\circ} \mathrm{C}$ but $1.5^{\circ} \mathrm{C}$ to avoid catastrophic ecological damage (IPCC 2018; Clémençon 2016) while promoting Type 2 reinforcing carbon pricing mechanisms as "central to prompt mitigation scenarios compatible with $1.5^{\circ} \mathrm{C}$ pathways" (IPCC 2018, 153). The contradictions become evident when even Nobel Laureate Nordhaus (2017) projects, when applying Type 2 reinforcing methods, that the economically optimal solution would produce (Type 4 undermining) warming of $3.1^{\circ} \mathrm{C}$ above pre-industrial levels.

Tragically, economic optimization scholars have addressed these contradictions through Type 2 reinforcing debates about the level of discount rates, rather than confronting their use for determining "rational" policy responses (Sprinz 2009; Winkler 2006; Barkin 2006; Hepburn and Stern 2008; Heal 1997). Similar drift helps explain why political scientists such as Victor $(2015,1)$ hailed the 2015 Paris Agreement owing to its ability to foster Type 3 compromise among competing interests even when acknowledging that the (Type 4) $1.5 / 2^{\circ} \mathrm{C}$ goal was "ridiculous" and that new (Type 3 ) goals were needed (Victor 2015, 4). These conclusions stood in contrast to Type 4 climate scientist James Hansen (2015) who, while accepting Victor's impact assessment, reasoned that the agreement was "a fraud really, a fake ... . Just worthless words" (Milman 2015).

\section{Finance and Market Driven (FMD) Policy Tools}

Type 4. It was in part owing to the frustration of environmental activists and Type 4 prioritization scholars with domestic and international policy responses that they turned to study "finance and market driven" (FMD) transnational policy tools originally offered in the early 1990 s as a way to design more efficient and effective solutions (Green 2010; Thomas et al. 2004).

Drift. Political and social science research on these governance innovations contributed to drift in two ways. First, with notable exceptions, most scholars focused on understanding the conditions through which these Type 2 reinforcing tools might gain support. Second, they emphasized "lessons learned" for policy designers to create synergies with Type 4 problems, including how to best coordinate and "stack" the proliferations of Type 2 FMD tools (Cooley and Olander 2011). The drift away from Type 4 problem conceptions was often reinforced by the research questions political scientists tended to ask, the methods they employed, and the type of data they collected.

\section{REDD+}

Consider widely cited research conducted by Chhatre and Ostrom's student Agrawal (2009) who applied a large-N statistical analysis to assess the synergistic potential of a public and private finance tool known as "reducing emissions from deforestation and forest degradation" (REDD+), which was formally institutionalized at the Bali Conference of the Parties for the UN climate change convention (COP) 13 in 2007 (Ebeling and Yasué 2008). Chhatre and Agrawal concluded that, if well designed, REDD + can foster synergies among Type 1 forestdependent communities, Type 2 economic development, and Type 4 problems including the climate crisis and biodiversity loss. Several social scientists have cited these findings as evidence that finance- and market-driven tools have strong potential to ameliorate Type 4 environmental problems (see, for example, Persha, Agrawal, and Chhatre 2011; Porter-Bolland et al. 2012; Schmitz 2018; Tobin 2020).

However, micro level research design choices appear to have led to drifts in empirical attention away from Type 4 problems. For example, their emphasis on "deforestation"- the common approach applied by political scientists who work on forests and climate (Lambin, Geist, and Lepers 2003) —often conflates or has difficulty distinguishing Type 1 logging and Type 4 forest conservation practices (figures 1 and 6). In addition, their decision to use readily available data on "basal area" of trees as a proxy for "above-ground carbon storage" was inconsistent with key biological features of complex forest carbon cycles (Bradford et al. 2016; Allison, Wallenstein, and Bradford 2010; Griscom et al. 2009). This analytic choice meant that it was not possible to infer from the data with any certainty that the REDD+ projects in question would have reduced or increased carbon emissions, let alone at levels consistent with the $1.5 / 2^{\circ} \mathrm{C}$ imperative. Most important, their analytical frames were not inductively derived from the structural features of a Type 4 problem, but rather, whether REDD+ performed relatively "better," when combined with Type 1 decentralization governance than with existing, rather than novel, inductively designed national government policies (see also Wright et al. 2016). This methodological decision is consistent with widespread norms among "data driven" forest scientists who measure the "effectiveness" of FMD tools based not on their ability to avert deforestation, but simply in reducing the rate of forest decline (Kuijk, Putz, 
and Zagt 2010). Differences in micro-level research design decisions may explain why, in contrast to Chhatre and Agrawal's recommending the stacking of local communal governance with REDD+ and other transnational FMD tools, Kill (2019) assessed REDD+ as a time-delaying approach - consistent with Dimitrov's (2019) concept of a "decoy institution"-while Milne et al. (2018) found REDD+ projects to be a "blunt tool for change," whose "dissonance between ... objectives and outcomes" rendered them unlikely to provide a solution in the global climate crisis.

\section{Certification/Eco-Labelling}

Similar drift has occurred in social science research on the emergence a quarter-century ago of supply chain efforts to certify consumer goods produced through environmentally friendly practices. Some of this occurred when Ostrom's students and followers (Prakash and Potoski 2006; Kolln and Prakash 2002) applied GTC's rationalist taxonomy to conceive of eco-labeling and voluntary programs not as institutions for solving environmental problems per se, but-through its treatment of them as "club goods" (table 2) —as the resource problem itself. This led to a research program that focused attention on why utility-enhancing firms might join, and implications for the ancillary environmental impacts that might result.

Similarly, compromise school political scientists would, by treating these eco-labeling efforts as new arenas of governance (Ruggie 2002), reinforce Type 3 conceptions by developing analytical frameworks that were derived from different ways in which organizations might support these systems, rather than from problem structure (Cashore, Auld, and Newsom 2004; Cashore 2002; Bernstein and Cashore 2007). Today, many of these scholars share widespread frustration about these supply-chain governance efforts' limited effects in ameliorating Type 4 problems (Bartley 2018; Grabs 2020). Yet until recently (Judge-Lord, McDermott, and Cashore 2020), most of these scholars-notably Cashore and collaborators-reinforced drift by conflating Type 1 and 4 problems when measuring, presenting, and characterizing what they referred to as environmental regulations (Cashore and Auld 2003; McDermott, Cashore, and Kanowski 2010; van der Ven, Rothacker, and Cashore 2018).

\section{Conclusion: Towards "Fit for Purpose" Policy Analysis}

What is evident from our review is that prevailing sustainability scholarship has narrowed an ability to ameliorate Type 4 problems to those that reinforce the moral frames of the compromise, economic optimization, and commons schools. These trends pose a philosophical puzzle for those who believe, despite fifty years of evidence to the contrary, that better designed policies can convert Type
4 whack-a-mole effects into synergies with Types 3, 2, and 1 (Prakash and Gupta 1996; Costanza 2006): if they are correct, then there is no harm in granting species extinctions and the climate crisis Type 4 prioritization status since subsequent thoughtful policy design will mean there are no economic moles to worry about. However, if they are incorrect, the dominance of the commons, economic optimization, and compromise schools will continue to contribute to environmental decline.

To be sure, Ostrom did deliberate over the problemsolving capacity of GTC's original framework (Ostrom 2007), going so far as to acknowledge "that humans have a more complex motivational structure ... than posited in earlier rational-choice theory" (Ostrom 2010), but still insisted that this complexity be incorporated into efforts to improve Type 1 "[utility undermining] collective action dilemmas." By the time of her Nobel Prize lecture she went further, but in so doing drifted away from problem structure, by advocating for universal analytical frames aimed at bringing out "the best in humans" (Ostrom 2010). However, none of these deliberations led to conceiving of the climate and species extinctions crises as Type 4 challenges, nor to giving the kind of systematic empirical attention to the collection of utility undermining environmental regulations (McDermott, Cashore, and Kanowski 2010) that she gave to Type 1 utility enhancing rules (Ostrom 2005).

How then might we reverse political science's role in accelerating Type 4 environmental crises? This is an important question, especially given the creation of two different research associations dominated by political scientists that have been formed with the expressed rhetorical purpose to help improve responses to environmental challenges: the European-based Earth Systems Governance network created by Frank Biermann that strongly incorporates compromise and prioritization schools and rigorous qualitative methods; and the U.S. based Annual Environmental Politics and Governance Conference founded by Ostrom's student Aseem Prakash, which emphasizes economic optimization and commons scholarship and sophisticated quantitative methods.

Key themes emerge to guide this exercise for bringing the environment back in. First, since all four schools draw on strong moral foundations, calls for greater attention to "ethics" for answers-especially when doing so biases Type 3 deliberative dialogues (Beauchamp 2007)—could undermine the prioritization school's sequentialist moral underpinnings. Recognition of this also informs debates within political science about the problems for which rational choice approaches are "fit for purpose" — such as, say, efforts to reduce humans' inefficient use of water consumption (Leong and Qian 2018).

Second, following GTC, we must be careful to avoid having today's prevailing research guiding metaphorssuch as "data-driven," "evidence based," "experimentalist," "scaling up," "bottom up," 
"nudging," "catalytic," "polycentric," "climate clubs," "free riding," "subsidiarity," "internalizing externalities," "multi-scalar," and even "intersectionality"-reinforce policy conception drift. Third, adopting methodological pluralism that characterized APSA's response to the 1990s Perestroika movement (Isaac 2015) may work to reinforce a compromise school approach that is also disconnected from problem structure. Recognition of this, in turn, poses fundamental questions about whether, by recommending interdisciplinary conversations across competing "world views" (Clapp and Dauvergne 2005) we reinforce Type 3 conceptions over Type 4 problem solving.

Fourth, "fit for purpose" policy analysis for averting catastrophic ecological effects of climate change will most certainly involve, as an increasing number of political and sustainability science scholars now recognize, much more careful assessments of the contribution of historical institutionalism with which to deliberate over and help design policy triggers capable of producing transformative change (Roberts et al. 2018; Rosenbloom, Meadowcroft, and Cashore 2019; Lockwood et al. 2017; Webster 2008; Geels 2005; Jordan and Moore 2020; Pahle et al. 2018). However, this turn still requires, in the case of climate change, the difficult task of distinguishing proposed triggers capable of advancing rather than overshooting a $1.5^{\circ} \mathrm{C}$ future (Auld et al. 2021, 11), as well as from those rationalist scholars who derive propositions about preference changing "norm cascades" (Hale 2020) on their ability to advance polycentric "catalytic cooperation" rather than Type 4 problem solving (ibid., 91).

To be sure, as highlighted by the German government's feed-in tariff program, prioritization school scholars will benefit from incorporating knowledge from other schools. For example, those trained in the economic optimization school designed a cost-effective "cap and trade" tool that helped companies meet, rather than avoid, Type 4 pollution regulations for whacking the Great Lake's acid rain mole (Burtraw and Swift 1996). Similarly, the compromise school has developed useful insights for designing stakeholder dialogues to co-generate knowledge surrounding complex Type 4 problems (Cashore et al. 2019; DíazReviriego, Turnhout, and Beck 2019).

What is clear from this review is that our tendency to drop the problem structure anchor when developing analytical frameworks has led political science researchers to be less equipped to incorporate scientific and policyrelevant knowledge for ameliorating a myriad of environmental problems. It therefore seems reasonable to conclude that our discipline has a duty to be transparent about the moral frames that dictate our analytical approaches and methodological choices, and the implications of doing so for either exacerbating or averting climate and massive species extinctions as the two most pressing, and soon to be irreversible, environmental problems facing our planet.

\section{Acknowledgements}

Cashore presented previous versions of this paper, or its framework, to the Copenhagen Business School's Department of Management, Society and Communication, January 2018; the International Studies Association's 2018 annual conference; the Ostrom Workshop, Bloomington, IN, April 23, 2018; plenary Session 3, "Climate Disorder and Public Policy: Governing in Turbulent Times," ICPP Montreal, June 28, 2019; the Copenhagen Business School's conference, "From Global Goals to Local Impact: Implementing Corporate Sustainability," June 20, 2019; the Jean Monnet Sustainable Development Goals Network's Policy Dialogue, Collaborative Approaches to Implementing the United Nations SDG Agenda, Singapore, June 13, 2019; and to the Lee Kuan Yew School of Public Policy's Research Seminar, May 7, 2018.

Cashore is grateful to Jeremy Moon, whose recommendation in the fall of 2017 that he expand from three problem types into four profoundly influenced this paper and related research projects. Cashore thanks Ashwath Dasarathy, Christopher Skelton, Hari Krishna, Kendra Wong, Hui Qi and Jagil Mehtab Ahmed for research assistance, and LKYSPP students in his Spring 2021 environmental and policy challenges classes who applied, and gave feedback, on the framework.

The authors thank four anonymous reviewers whose comments greatly improved the analysis and argument, and for specific comments from Guy Peters, Jette Knudsen, Michael Fotos, Noel Semple, Ken Gillingham, Lee Alston, David Konisky, Jimmy Walker, Burney Fischer, Barbara Cherry, Daniel Cheng, Eduardo Brondizio, Martin Delaroche, Jessica Steinberg, Jon Eldon, Jessy O'Reilly, Ken Richard, Karen Seto, Detlef Sprinz, Cristina Y.A. Inoue, Dimitris Stevis, Michael Maniates, Tom Princen, Michael Albert, Clayton Dasilva, Yelda Erçandirlı, Sina Leipold, Steven Wolfe, Gus Speth, Amity Doolittle, Paul Edwards, Narasimha Rao, Mary Evelyn Tucker, John Grimm, Doug Kysar, Susan Clark, Paul Anastas, Anthony Leiserowitz, Emma Shortis, Bruce Wilson, Hamish Van Der Ven, Gabe Benoit, Indy Burke, Caroline Compton, Janina Grabs, Graeme Auld, Reuben Kline, Robyn Eckersley, Neil Gunningham, Raymond Clémençon, Adam Rome, Ishani Mukherjee, Lahiru Wijedasa, Craig Thomas, Peter Christoff, Devin JudgeLord, Hongzhou Zhang, Joshua C. Gellers, Zeewan Lee, Dan Han, Liuyang He, Ingrid Visseren-Hamakers, Ed Araral, Vinod Thomas, Derk Loorbach, Pieter Vullers, Marcel Kok, Theresa Cashore, Donna Krejci, Kelly Levin, Charlotte Streck, Daniela Goehler, and Tom Pegram.

Support for this research was provided by a National University of Singapore Start Up Grant through the Lee Kuan Yew School of Public Policy. Open access was provided by the Lee Kuan Yew School of Public Policy's Academic Research Support Fund. 


\section{Notes}

1 All italics in the quotes in this article are added by the authors.

2 For clarity, we refer to "problem conception types" when discussing cognitive differences, and "problem types" when reviewing empirical outcomes.

3 An arcade game in which a mallet is used to strike a mole popping out of one hole only to have another mole appear in another hole.

4 Our thanks to Guy Peters for this observation.

\section{References}

Ackerman, Frank, and Lisa Heinzerling. 2004. Priceless: On Knowing the Price of Everything and the Value of Nothing. New York: The New Press.

Adler, Matthew, and Eric A. Posner. 2009. "New Foundations of Cost-Benefit Analysis." Regulation \& Governance 3(1): 72-83.

Aklin, Michaël, and Matto Mildenberger. 2017. "Prisoners of the Wrong Dilemma: Why Distributive Conflict, Not Collective Action, Characterizes the Politics of Climate Change." Unpublished manuscript. https://doi.org/10.1162/glep_a_00578

Allin, C.W. 1982. The Politics of Wilderness Protection. Westport, CT: Greenwood Press.

Allison, Steven D., Matthew D. Wallenstein, and Mark A. Bradford. 2010. "Soil-Carbon Response to Warming Dependent on Microbial Physiology." Nature Geoscience 3(5): 336-40.

Andersson, Krister P., Tom P. Evans, and Kenneth R. Richards. 2009. "National Forest Carbon Inventories: Policy Needs and Assessment Capacity." Climatic Change 93(1-2): 69-101.

Andersson, Krister P., and Elinor Ostrom. 2008. "Analyzing Decentralized Resource Regimes from a Polycentric Perspective." Policy Sciences 41(1): 71-93.

Araral, Eduardo. 2014. "Ostrom, Hardin and the Commons: A Critical Appreciation and a Revisionist View." Environmental Science and Policy 36: 11-23.

Arrow, Kenneth J., Maureen L. Cropper, George C. Eads, Robert W. Hahn, Lester B. Lave, Roger G. Noll, Paul R. Portney, et al. 1996. "Is There a Role for Benefit-Cost Analysis in Environmental, Health, and Safety Regulation?" Science 272(5259): 221-22.

Auld, Graeme, Steven Bernstein, Benjamin Cashore, and Kelly Levin. 2021. "Managing Pandemics as Super Wicked Problems: Lessons from, and for, COVID-19 and the Climate Crisis." Policy Sciences 54: 707-728.

Awan, Abdul Ghafoor. 2013. "Relationship between Environment and Sustainable Economic Development: A Theoretical Approach to Environmental Problems." International Journal of Asian Social Science 3(3): 741-61.
Bachrach, Peter, and Morton S. Baratz. 1962. "Two Faces of Power." American Political Science Review 56(4): 947-52.

Bacow, L., and M. Wheeler. 1984. Environmental Dispute Resolution. New York: Plenum Press.

Baker, Susan C., Simon J. Grove, Lynne Forster, Kevin J. Bonham, and Dick Bashford. 2009. "Short-Term Responses of Ground-Active Beetles to Alternative Silvicultural Systems in the Warra Silvicultural Systems Trial, Tasmania, Australia." Forest Ecology and Management 258(4): 444-59.

Barkin, J. Samuel. 2006. "Discounting the Discount Rate: Ecocentrism and Environmental Economics." Global Environmental Politics 6(4): 56-72.

Barkin, J. Samuel, and George Shambaugh. 1999. "Hypotheses on the International Politics of Common Pool Resources." In Anarchy and the Environment: The International Relations of Common Pool Resources, ed. J.S. Barkin and G. Shambaugh, 1-25. Albany: SUNY Press.

Barry, John, and Robyn Eckersley. 2005. The State and the Global Ecological Crisis. Cambridge, MA: MIT Press.

Bartley, Tim, Krister P. Andersson, Pamela Jagger, and Frank Van Laerhoven. 2008. "The Contribution of Institutional Theories to Explaining Decentralization of Natural Resource Governance." Society and Natural Resources 21(2): 160-74.

Bartley, Timothy. 2018. Rules without Rights: Land, Labor and Private Authority in the Global Economy. New Haven, CT: Oxford University Press.

Beauchamp, Tom L. 2007. “The 'Four Principles' Approach to Health Care Ethics." Principles of Health Care Ethics 29: 3-10.

Bernstein, Steven. 2001. The Compromise of Liberal Environmentalism. New York: Columbia University Press.

Bernstein, Steven, and Benjamin Cashore. 2007. "Can Non-State Global Governance Be Legitimate? An Analytical Framework." Regulation and Governance 1(4): 347-71.

Bernstein, Steven, Richard Ned Lebow, Janice Gross Stein, and Steven Weber. 2000. "God Gave Physics the Easy Problems: Adapting Social Science to an Unpredictable World." European Journal of International Relations 66(1): 43-76.

Berrill, Michael. 1997. The Plundered Seas. San Francisco: Sierra Club Books.

Bishop, Kevin, Adrian Phillips, and Lynda Warren. 1995. "Protected for Ever? Factors Shaping the Future of Protected Areas Policy." Land Use Policy 12(4): 291-305.

Bodansky, Daniel. 1999. "The Legitimacy of International Governance: A Coming Challenge for 
International Environmental Law?" American Journal of International Law 93(3): 596-624.

Bowen, Kathryn J., Nicholas A. Cradock-Henry, Florian Koch, James Patterson, Tiina Häyhä, Jess Vogt, and Fabiana Barbi. 2017. "Implementing the 'Sustainable Development Goals': Towards Addressing Three Key Governance ChallengesCollective Action, Trade-Offs, and Accountability." Current Opinion in Environmental Sustainability 26-27: 90-96.

Brach, Darshan, Patrick Field, Lawrence Susskind, and William A. Tilleman. 2002. "Overcoming the Barriers to Environmental Dispute Resolution in Canada." Canadian Bar Review 81(2): 396-430.

Bradford, Mark A., William R. Wieder, Gordon B. Bonan, Noah Fierer, Peter A. Raymond, and Thomas W. Crowther. 2016. "Managing Uncertainty in Soil Carbon Feedbacks to Climate Change." Nature Climate Change 6(8): 751-58.

Brondizio, Eduardo S., Elinor Ostrom, and Oran R. Young. 2009. "Connectivity and the Governance of Multilevel Social-Ecological Systems: The Role of Social Capital." Annual Review of Environment and Resources 34(1): 253-78.

Bryant, Sally, and Jean Jackson. 1999. "Tasmania's Threatened Fauna Handbook." Hobart: Threatened Species Unit, Parks and Wildlife Service Tasmania. (https://dpipwe.tas.gov.au/Documents/ threatfauna.pdf).

Buck, Susan. 1998. "No Tragedy of the Commons." In Green Planet Blues: Environmental Politics from Stockholm to Rio, ed. K. Conca, M. Alberty and G. Dabelko. Boulder, CO: Westview Press.

Burtraw, Dallas, and Byron Swift. 1996. "A New Standard of Performance: An Analysis of the Clean Air Act's Acid Rain Program.” Environmental Law Reporter News \& Analysis 26: 10411.

Carpenter, Stephen R., Harold A. Mooney, John Agard, Doris Capistrano, Ruth S. DeFries, Sandra Diaz, Thomas Dietz, et al. 2009. "Science for Managing Ecosystem Services: Beyond the Millennium Ecosystem Assessment." Proceedings of the National Academy of Sciences 106(5): 1305-12.

Carson, Rachel. 1962. Silent Spring. Boston: Houghton Mifflin.

Cashore, Benjamin. 2002. "Legitimacy and the Privatization of Environmental Governance: How Non-State Market Driven (NSMD) Governance Systems Gain Rule-Making Authority." Governance 15(4): 503-29.

Cashore, Benjamin, and Graeme Auld. 2003. "The British Columbia Environmental Forest Policy Record in Comparative Perspective." Journal of Forestry (8): 42-47.
Cashore, Benjamin, Steven Bernstein, David Humphreys, Ingrid Visseren-Hamakers, and Katharine Rietig. 2019. "Designing Stakeholder Learning Dialogues for Effective Global Governance." Policy and Society 38(1): 118-147.

Cashore, Benjamin, and Michael Howlett. 2007. "Punctuating Which Equilibrium? Understanding Thermostatic Policy Dynamics in Pacific Northwest Forestry." American Journal of Political Science 51(3): 532-551.

Cashore, Benjamin William, Graeme Auld, and Deanna Newsom. 2004. Governing through Markets: Forest Certification and the Emergence of Non-State Authority. New Haven, CT: Yale University Press.

Chhatre, Ashwini, and Arun Agrawal. 2009. "TradeOffs and Synergies between Carbon Storage and Livelihood Benefits from Forest Commons."

Proceedings of the National Academy of Sciences 106(42): 17667-70.

Clapp, Jennifer, and Peter Dauvergne. 2005. Paths to a Green World: The Political Economy of the Global Environment. Cambridge, MA: MIT Press.

Clark, Susan G., and Richard L. Wallace. 2011. "Integration and Interdisciplinarity: Concepts, Frameworks, and Education." Policy Sciences 48(2): 233-55.

Clémençon, Raymond. 2012. "Welcome to the Anthropocene: Rio+20 and the Meaning of Sustainable Development." Journal of Environment \& Development 21(3): 311-38.

- 2016. "The Two Sides of the Paris Climate Agreement: Dismal Failure or Historic Breakthrough?" Journal of Environment \& Development 25(1): 3-24.

_ 2021. "Is Sustainable Development Bad for Global Biodiversity Conservation?" Global Sustainability 4: E14. doi:10.1017/sus.2021.14

Coglianese, Cary. 1997. "Assessing Consensus: The Promise and Performance of Negotiated Rulemaking." Duke Law Journal 46(6): 1255-349.

Conca, Ken, Thomas Princen, and Michael F. Maniates. 2001. "Confronting Consumption." Global Environmental Politics 1(3): 1-10.

Cooley, David, and Lydia Olander. 2011. "Stacking Ecosystem Services Payments Risks and Solutions Risks and Solutions." Working paper NI WP 11-04. Nicholas Institute for Environmental Policy Solutions, Duke University. (https://nicholasinstitute.duke.edu/ sites/default/files/publications/stacking-ecosystemservices-payments-paper.pdf).

Costanza, Robert. 2006. "Nature: Ecosystems without Commodifying Them.” Nature 443: 749-49. https:// doi.org/10.1038/443749b 
Crowfoot, James E., and Julia Wondolleck. 1991. Environmental Disputes: Community Involvement in Conflict Resolution. Washington, DC: Island Press.

Curran, L., and S. Trigg. 2006. "Sustainability Science from Space: Quantifying Forest Disturbance and LandUse Dynamics in the Amazon." Proceedings of the National Academy of Sciences of the United States of America 103(34): 12663-64.

Czech, Brian, and Paul R. Krausman. 1999. "Research Notes Public Opinion on Endangered Species Conservation and Policy." Society \& Natural Resources 12(5): 469-79.

Dahl, Robert. 1961. Who Governs: Democracy and Power in an American City. New Haven, CT: Yale University Press.

Dauvergne, Peter. 2001. Loggers and Degradation in the Asia Pacific: Corporations and Environmental Management. New York: Cambridge University Press.

Díaz-Reviriego, Isabel, Esther Turnhout, and Silke Beck. 2019. "Participation and Inclusiveness in the Intergovernmental Science-Policy Platform on Biodiversity and Ecosystem Services." Nature Sustainability 2(6): 457-64.

Dietz, Thomas, Elinor Ostrom, and Paul C. Stern. 2003. "The Struggle to Govern the Commons." Science 302 (5652): 1907-12.

Dimitrov, Radoslav S. 2019. "Empty Institutions in Global Environmental Politics." International Studies Review 22(3): 626-60.

Dryzek, John S. 1990. Discursive Democracy: Politics, Policy, and Political Science. New York: Cambridge University Press.

Dunlap, Riley E. 1992. "Trends in Public Opinion toward Environmental Issues: 1965-1990.” In American Environmentalism: The US Environmental Movement, 1970-1990, ed. R. E. Dunlap and A. Mertig, 89-116. Philadelphia: Taylor \& Francis.

Ebeling, Johannes, and Maï Yasué. 2008. "Generating Carbon Finance through Avoided Deforestation and Its Potential to Create Climatic, Conservation and Human Development Benefits." Philosophical Transactions of the Royal Society B: Biological Sciences 363(1498): 1917-24.

Elster, Jon, ed. 1986. Rational Choice. Oxford: Basil Blackwell.

Environmental Protection Agency. Mortality Risk Valuation. U.S. EPA 2020. (https://www.epa.gov/ environmental-economics/mortality-riskvaluation\#whatvalue).

Falkner, Robert. 2016. "A Minilateral Solution for Global Climate Change? On Bargaining Efficiency, Club Benefits, and International Legitimacy." Perspectives on Politics 14(1): 87-101.

FAOSTAT. 2020. "Forestry Data." United Nations Food and Agriculture Organization. (http://www.fao.org/ faostat/en/\#home) at Forestry and Trade (http://www. fao.org/faostat/en/\#data/FO).

Farr, James, Jacob S. Hacker, and Nicole Kazee. 2006. "The Policy Scientist of Democracy: The Discipline of Harold D. Lasswell." American Political Science Review 100(4): 579-87.

Farrell, Justin. 2020. Billionaire Wilderness: The UltraWealthy and the Remaking of the American West. Vol. 83, Princeton Studies in Cultural Sociology. Princeton, NJ: Princeton University Press.

Forests Dialogue. 2018. "Key Lessons for Community Engagement in Forest Landscapes: Learning from 17 Years of TFD's Initiatives." New Haven, CT: The Forests Dialogue, School of Forestry and Environmental Studies, Yale University.

Franklin, Jerry. 1994. "A Conceptual Basis for Femat: Ecological Science.” Journal of Forestry 92(4): 21-23.

Gale, Fred P. 1998. The Tropical Timber Trade Regime. New York: St. Martin's Press.

Geels, Frank W. 2005. "Processes and Patterns in Transitions and System Innovations: Refining the Co-Evolutionary Multi-Level Perspective.” Technological Forecasting and Social Change 72(6): 681-96.

Giaari, Albert. 1994. "The Endangered Species Act: Impact of Section 9 on Private Landowners." Environmental Law 24(2): 419-500.

Gibson, Clark C., Margaret A. McKean, and Elinor Ostrom, eds. 2000. People and Forests: Communities, Institutions and Governance. Cambridge, MA: MIT Press.

Gorte, Ross W. 1993. “The Clinton Administration's Forest Plan for the Pacific Northwest." Congressional Research Service, Library of Congress. (https:// www.washington.edu/uwired/outreach/cspn/Website/ Classroom\%20Materials/Curriculum\%20Packets/ Evergreen\%20State/Documents/document\% 2055.html).

Grabs, Janina. 2020. Selling Sustainability Short? The Private Governance of Labor and the Environment in the Coffee Sector. New York: Cambridge University Press.

Green, Donald P., and Ian Shapiro. 1995. "Pathologies Revisited: Reflections on Our Critics." Journal of Politics and Society 9(1-2): 235-76.

Green, Jessica F. 2010. "Private Standards in the Climate Regime: The Greenhouse Gas Protocol." Business and Politics 12(3): 1-37.

- 2021. "Does Carbon Pricing Reduce Emissions? A Review of Ex-Post Analyses." Environmental Research Letters. (https://iopscience.iop.org/article/10.1088/ 1748-9326/abdae9).

- 2018. "Why We Need a More Activist Academy: Impartiality Bolsters a Dangerous Status Quo." The Chronicle Review, July 15. (https:// www.chronicle.com/article/why-we-need-a-moreactivist-academy/). 
Griscom, Bronson, David Ganz, Nicole Virgilio, Fran Price, Jeff Hayward, Rane Cortez, Gary Dodge, et al. 2009. "The Hidden Frontier of Forest Degradation: A Review of the Science, Policy and Practice of Reducing Degradation Emissions.” Arlington, VA: The Nature Conservancy.

Grove, Simon J. 2002. "Saproxylic Insect Ecology and the Sustainable Management of Forests." Annual Review of Ecology and Systematics 33(1): 1-23.

Habermas, Jürgen. 1973. Legitimation Crisis. Boston: Beacon Press.

Halbert, Cindy, and Kai Lee. 1990. "The Timber, Fish, and Wildlife Agreement: Implementing Alternative Dispute Resolution in Washington State." Northwest Environmental Journal 6: 139-175.

Hale, Thomas. 2020. "Catalytic Cooperation.” Global Environmental Politics 20(4): 73-98.

Hall, Peter. 1993. "Policy Paradigms, Social Learning, and the State: The Case of Economic Policymaking in Britain." Comparative Politics 25(3): 275-96.

Hardin, Garrett. 1968. "The Tragedy of the Commons." Science 162(3859): 1243-48.

Heal, G. 1997. "Discounting and Climate Change." Climatic Change 37(2): 335-43.

Hepburn, Cameron, and Nicholas Stern. 2008. "A New Global Deal on Climate Change." Oxford Review of Economic Policy 24(2): 259-79.

Herman, Edward S., and Noam Chomsky. 1988. Manufacturing Consent: The Political Economy of the Mass Media. New York: Pantheon Books.

Hoberg, George. 1992. Pluralism by Design: Environmental Policy and the American Regulatory State. New York: Praeger.

Hovi, Jon, Detlef F. Sprinz, and Arild Underdal. 2003. "Regime Effectiveness and the Oslo-Potsdam Solution: A Rejoinder to Oran Young." Global Environmental Politics 3(3): 105-107.

Howlett, Michael. 2019. Designing Public Policies: Principles and Instruments. New York: Routledge.

Humphreys, David. 2006. Logjam: Deforestation and the Crisis of Global Governance. London: Earthscan.

Independent Group of Scientists. 2019. "The Future Is Now: Science for Achieving Sustainable Development." Global Sustainable Development Report 2019. New York: United Nations.

Inglehart, Ronald. 1995. "Public Support for Environmental Protection: Objective Problems and Subjective Values in 43 Societies." PS: Political Science of Politics 28(1): 57-73.

IPBES. 2019. "Global Assessment Report on Biodiversity and Ecosystem Services.” Bonn: Intergovernmental SciencePolicy Platform on Biodiversity and Ecosystem Services. IPCC. 2018. "Special Report: Global Warming of $1.5^{\circ} \mathrm{C}$." Geneva, Switzerland: World Meteorological Organization.
Isaac, Jeffrey C. 2015. "For a More Public Political Science." Perspectives on Politics 14(1): 87-101.

Ivanova, Maria. 2021. A Revisionist History of the World's Leading Environmental Institution: UNEP at Fifty. Cambridge, MA: MIT Press.

Jacobsen, Kim S., and John D.C. Linnell. 2016. "Perceptions of Environmental Justice and the Conflict Surrounding Large Carnivore Management in Norway -Implications for Conflict Management.” Biological Conservation 203: 197-206. https://doi.org/10.1016/ j.biocon.2016.08.041

Javeline, Debra. 2014. "The Most Important Topic Political Scientists Are Not Studying: Adapting to Climate Change." Perspectives on Politics 12(2): 400-32.

Jordan, Andrew J., and Brendan Moore. 2020. Durable by Design? Policy Feedback in a Changing Climate. New York: Cambridge University Press.

Judge-Lord, Devin, Constance L. McDermott, and Benjamin Cashore. 2020. "Do Private Regulations Ratchet Up? How to Distinguish Types of Regulatory Stringency and Patterns of Change." Organization \& Environment 33(1): 96-125.

Kaldor, Nicholas. 1939. "Welfare Propositions of Economics and Interpersonal Comparisons of Utility." Economic Journal 49(195): 549-52.

Kates, Robert W. 2011. "What Kind of a Science Is Sustainability Science?" Proceedings of the National Academy of Sciences of the United States of America 108(49): 19449-50.

Kenny, Anthony. 2011. Life, Liberty and the Pursuit of Utility: Happiness in Philosophical and Economic Thought. Vol. 7, St. Andrews Studies in Philosophy and Public Affairs. Exeter, UK: Imprint Academic.

Keohane, Robert O., and David G. Victor. 2016. "Cooperation and Discord in Global Climate Policy." Nature Climate Change 6(6): 570-75.

Kill, Jutta. 2019. "Redd+: A Lost Decade for International Forest Conservation.” Berlin: Heinrich Boll Stiftung e.V.

Kohm, Kathryn A. 1991. Balancing on the Brink of Extinction: The Endangered Species Act and Lessons for the Future. Washington, DC: Island Press.

Kolln, Kelly, and Aseem Prakash. 2002. "EMS-Based Environmental Regimes as Club Goods: Examining Variations in Firm-Level Adoption of ISO 14001 and EMAS in U.K., U.S. and Germany.” Policy Sciences 35 (1): 43-67.

Koontz, T. M., and C. W. Thomas. 2006. "What Do We Know and Need to Know about the Environmental Outcomes of Collaborative Management?" Public Administration Review 66(S1): 111-21.

Kuijk, Marijke van, Francis E. Putz, and Roderick Zagt. 2010. "Effects of Forest Certification on Biodiversity." Tropenbos International. 
Kütting, Gabriela. 2000. Environment, Society, and International Relations: Towards More Effective International Environmental Agreements. London: Routledge.

Lambin, Eric F., Helmut J. Geist, and Erika Lepers. 2003. "Dynamics of Land-Use and Land-Cover Change in Tropical Regions." Annual Review of Environment and Resources 28: 205-41.

Lange, Jonathan I. 1993. "The Logic of Competing Information Campaigns: Conflict over Old Growth and the Spotted Owl." Communications Monographs 60(3): 239-57.

Laurance, William F., and Diana C. Useche. 2009. "Environmental Synergisms and Extinctions of Tropical Species." Conservation Biology 23(6): 1427-37.

Leader-Williams, N., J. Harrison, and M.J.B. Green. 1990. "Designing Protected Areas to Conserve Natural Resources." Science Progress 74(2): 189-204.

Leong, Ching, and Neng Qian. 2018. "Why Contracts Fail: A Game Theoretic Approach to Managing Urban Water." Urban Water Journal 15(4): 353-61.

Levin, Kelly, Benjamin Cashore, Steven Bernstein, and Graeme Auld. 2012. "Overcoming the Tragedy of Super Wicked Problems: Constraining Our Future Selves to Ameliorate Global Climate Change." Policy Sciences 45(2): 123-52.

Levy, David L., and Daniel Egan. 1998. "Capital Contests: National and Transnational Channels of Corporate Influence on the Climate Change Negotiations." Politics \& Society 26(3): 337-61.

Lindblom, Charles E. 1977. Politics and Markets: The World's Political Economic Systems. New York: Basic Books.

Lindenmayer, David B., and Jerry F. Franklin, eds. 2003. Towards Forest Sustainability. Washington, DC: Island Press.

Lippke, Bruce R., J. Keith Gilles, Robert G. Lee, and Paul E. Sommers. 1990. "Three-State Impact of Spotted Owl Conservation and Other Timber Harvest Reductions: A Cooperative Evaluation of the Economic and Social Impacts." University of Washington, University of California, Oregon State University Institute of Forest Resources.

Lockwood, Matthew, Caroline Kuzemko, Catherine Mitchell, and Richard Hoggett. 2017. "Historical Institutionalism and the Politics of Sustainable Energy Transitions: A Research Agenda." Environment and Planning C: Politics and Space 35(2): 312-33.

Lomborg, Bjorn. 2001. The Skeptical Environmentalist. New York: Cambridge University Press.

LPI. 2016. "Living Planet Index Database." Zoolgical Society of London and WWE.
Luke, Timothy W. 2009. "Developing Planetarian Accountancy: Fabricating Nature as Stock, Service, and System for Green Governmentality." In Nature, Knowledge and Negation, ed. H.F. Dahms, 129-159. Bingley: Emerald Group Publishing Limited.

Lukes, Steven. 1974. Power: A Radical View. London: MacMillan Press, Ltd.

March, James G., and Johan P. Olsen. 1998. "The Institutional Dynamics of International Political Orders." International Organization 52(4): 943-69.

Markham, Adam. 1996. "Potential Impacts of Climate Change on Ecosystems: A Review of Implications for Policymakers and Conservation Biologists." Climate Research 6(2): 179-91.

Matson, Pamela, William C. Clark, and Krister Andersson. 2016. Pursuing Sustainability: A Guide to the Science and Practice. Princeton, NJ: Princeton University Press.

McAfee, Kathleen. 1999. "Selling Nature to Save It? Biodiversity and Green Developmentalism." Environment and Planning D: Society and Space 17(2): 133-54.

McCauley, Douglas J. 2006. "Selling Out on Nature." Nature 443(7107): 27-28.

McDermott, Constance L., Benjamin Cashore, and Peter Kanowski. 2010. Global Environmental Forest Policies: An International Comparison. London: Earthscan.

Meadows, Donella H., Dennis L. Meadows, Jørgen Randers, and William W. Behrens, III. 1972. The Limits to Growth: A Report for the Club of Rome's Project on the Predicament of Mankind. New York: Universe Books.

Meckling, Jonas. 2019. "A New Path for U.S. Climate Politics: Choosing Policies That Mobilize Business for Decarbonization." ANNALS of the American Academy of Political and Social Science 685(1): 82-95.

Milman, Oliver. 2015. "James Hansen, Father of Climate Change Awareness, Calls Paris Talks 'a Fraud'." The Guardian, December 12.

Milne, Sarah, Sango Mahantya, Phuc Toa, Wolfram Dressler, Peter Kanowski, and Maylee Thavata. 2018. "Learning from 'Actually Existing' Redd+: A Synthesis of Ethnographic Findings." Conservation and Society 17(1): 84-95.

Mitchell, Ronald B, and Charli Carpenter. 2019. "Norms for the Earth: Changing the Climate on 'Climate Change.." Journal of Global Security Studies 4(4): 413-429.

Nair, K.S. Sadasivan. 2007. Tropical Forest Insect Pests: Ecology, Impact, and Management. New York: Cambridge University Press.

Najam, Adil, and Ambuj Sagar. 1998. "Avoiding a CopOut: Moving towards Systematic Decision-Making under the Climate Convention." Climatic Change 39(4): 3-9. 
Nash, John. 1953. "Two-Person Cooperative Games." Econometrica: Journal of the Econometric Society 21(1): 128-40.

NASA. Global Climate Change. National Aeronautics and Space Administration 2020. (https://climate.nasa.gov/ vital-signs/global-temperature/).

Neville, Kate J., and Matthew Hoffmann. 2018.

"Global Environmental Politics Research in a Time of Crisis." In A Research Agenda for Global Environmental Politics, ed. Peter Dauvergne and Justin Alger, 177-190. Northampton, MA: Edward Elgar Publishing.

Nilsson, Måns, and Nina Weitz. 2019. "Governing Trade-Offs and Building Coherence in Policy-Making for the 2030 Agenda." Politics and Governance 7(4): 254-63.

Nordhaus, William D. 1991. "To Slow or Not to Slow: The Economics of the Greenhouse-Effect." Economic Journal 101(407): 920-37.

- 2017. "Revisiting the Social Cost of Carbon." Proceedings of the National Academy of Sciences 114(7): 1518-23.

North, Douglass C. 1990. Institutions, Institutional Change and Economic Performance. New York: Cambridge University Press.

OECD. 1972. 'PPP to be the 'Guiding Principle Concerning the International Economic Aspects of Environmental Policies' recommendation," the Council of the Organization for Economic Cooperation and Development, May 26, 1972. Paris: Organisation on Economic Co-operation and Development.

Olson, Mancur. 1965. The Logic of Collective Action: Public Goods and the Theory of Groups. Cambridge, MA: Harvard University Press.

Ostrom, Elinor. 1990. Governing the Commons: The Evolution of Institutions for Collective Action. Cambridge: Cambridge University Press.

- 1998. "A Behavioral Approach to the Rational Choice Theory of Collective Action." American Political Science Review 92(1): 1-22.

—. 2003. "How Types of Goods and Property Rights Jointly Affect Collective Action." Journal of Theoretical Politics 15(3): 239-70.

- 2005. Understanding Institutional Diversity.

Princeton, NJ: Princeton University Press.

—. 2007. "A Diagnostic Approach for Going Beyond

Panaceas." Proceedings of the National Academy of

Sciences of the United States of America 104(39):

15181-87.

- 2010. "Beyond Markets and States: Polycentric Governance of Complex Economic Systems." American Economic Review 100(3): 641-72.

Ostrom, Elinor, and Vincent Ostrom. 1972. "A Theory for Institutional Analysis of Common Pool Problems."
In Managing the Commons, eds. G. Hardin and J. Baden. San Francisco: W.H. Freeman.

Ovodenko, Alexander, and Robert O. Keohane. 2012.

"Institutional Diffusion in International

Environmental Affairs." International Affairs 88(3): 523-41.

Paddle, Robert. 2002. The Last Tasmanian Tiger: The History and Extinction of the Thylacine. New York: Cambridge University Press.

Paehlke, Robert C. 1989. Environmentalism and the Future of Progressive Politics. New Haven, CT: Yale University Press.

Pahle, Michael, Dallas Burtraw, Christian Flachsland, Nina Kelsey, Eric Biber, Jonas Meckling, Ottmaro Edenhofer, and John Zysman. 2018. "Sequencing to Ratchet Up Climate Policy Stringency." Nature Climate Change 8(10): 861-67.

Perez-Garcia, John. 1993. "Global Forestry Impacts of Reducing Softwood Supplies from North America." Working Paper 43. Center for International Trade in Forest Products, College of Forest Resources, University of Washington.

Persha, Lauren, Arun Agrawal, and Ashwini Chhatre. 2011. "Social and Ecological Synergy: Local Rulemaking, Forest Livelihoods, and Biodiversity Conservation." Science 331(6024): 1606-608.

Pierson, Paul. 1993. "When Effect Becomes Cause: Policy Feedback and Political Change." World Politics 45(4): 595-628.

Piketty, Thomas. 2015. The Economics of Inequality. Cambridge, MA: Harvard University Press.

Pinchot, Gifford. 1987. Breaking New Ground. Washington, DC: Island Press.

Pinkerton, Evelyn W. 1993. "Co-Management Efforts as Social Movements: The Tin Wis Coalition and the Drive for Forest Practices Legislation in British Columbia." Alternatives 19(3): 33-38.

Porter-Bolland, Luciana, Edward A. Ellis, Manuel R. Guariguata, Isabel Ruiz-Mallén, Simoneta NegreteYankelevich, and Victoria Reyes-García. 2012. "Community Managed Forests and Forest Protected Areas: An Assessment of Their Conservation Effectiveness across the Tropics." Forest Ecology and Management 268: 6-17.

Prakash, Aseem, and Anil K. Gupta. 1996. "Ecologically Sustainable Institutions.” In Environmental Sustainability: Practical Global Implications, ed. F. Smith, 47-66. Boca Raton, FL: St. Lucie Press.

Prakash, Aseem, and Matthew Potoski. 2006. The Voluntary Environmentalists. Green Clubs, ISO 14001, and Voluntary Environmental Regulations. Cambridge: Cambridge University Press.

Rawls, John. 1971. A Theory of Justice, Revised Edition. Cambridge, MA: Harvard University Press. 
Rawls, R. Patrick, and David N. Laband. 2004. "A Public Choice Analysis of Endangered Species Listings." Public Choice 121(3/4): 263-77.

Raymond, Mark, and Laura DeNardis. 2015.

"Multistakeholderism: Anatomy of an Inchoate Global Institution." International Theory 7(3): 572-616.

Reed, James, Jos Barlow, Rachel Carmenta, Josh van Vianen, and Terry Sunderland. 2019. "Engaging

Multiple Stakeholders to Reconcile Climate,

Conservation and Development Objectives in

Tropical Landscapes.” Biological Conservation 238:

108229. https://doi.org/10.1016/

j.biocon.2019.108229

Roberts, Cameron, Frank W. Geels, Matthew

Lockwood, Peter Newell, Hubert Schmitz, Bruno

Turnheim, and Andy Jordan. 2018. "The Politics of

Accelerating Low-Carbon Transitions: Towards a New

Research Agenda." Energy Research \& Social Science 44: 304-11.

Rosenbloom, Daniel, James Meadowcroft, and Benjamin Cashore. 2019. "Stability and Climate Policy?

Harnessing Insights on Path Dependence, Policy

Feedback, and Transition Pathways." Energy Research \& Social Science 50: 168-78.

Rosenbluth, Frances, and Ian Shapiro. 2018. Responsible Parties: Saving Democracy from Itself. New Haven, CT: Yale University Press.

Ruggie, John Gerard. 2002. "The Theory and Practice of Learning Networks: Corporate Social Responsibility and the Global Compact." Journal of Corporate Citizenship 5: 27-35. http://dx.doi.org/10.9774/ GLEAF.4700.2002.sp.00005

Sabatier, Paul A. 1988. "The Advocacy Coalition Framework." Policy Sciences 21: 129-168.

Sachs, Jeffrey, Joseph Stiglitz, Mariana Mazzucato, Clair Brown, Indivar Dutta-Gupta, Robert Reich, Gabriel Zucman, and many others. 2020. "Letter from Economists: To Rebuild Our World, We Must End the Carbon Economy.” The Guardian, May 14. (https:// www.theguardian.com/commentisfree/2020/aug/04/ economists-letter-carbon-economy-climate-changerebuild).

Saez, C.A., and J.C. Requena. 2007. "Reconciling Sustainability and Discounting in Cost-Benefit Analysis: A Methodological Proposal." Ecological Economics 60(4): 712-25.

Scharpf, Fritz. 1999. Governing in Europe: Effective and Democratic? Oxford: Oxford University Press.

Schmid, Nicolas, Sebastian Sewerin, and Tobias S. Schmidt. 2019. "Explaining Advocacy Coalition Change with Policy Feedback." Policy Studies Journal 48 (4): 1109-34.

Schmitz, Oswald J. 2018. The New Ecology: Rethinking a Science for the Anthropocene. Princeton, NJ: Princeton University Press.
Sell, Joachim, Thomas Koellner, Olaf Weber, Wendy Proctor, Lucio Pedroni, and Roland W. Scholz. 2007. "Ecosystem Services from Tropical Forestry Projects: The Choice of International Market Actors." Forest Policy and Economics 9(5): 496-515.

Sen, Amartya. 1979. "Personal Utilities and Public Judgements: Or What's Wrong with Welfare Economics." Economic Journal 89(355): 537-58.

Sethi, Rajiv, and E. Somanathan. 1996. "The Evolution of Social Norms in Common Property Resource Use." American Economic Review 86(4): 766-88.

Shands, William E. 1988. "Beyond Multiple Use: Managing National Forests for Distinctive Values." American Forests 94(3-4): 14-15, 56-57.

Shapiro, Ian. 2007. The Flight from Reality in the Human Sciences. Princeton, NJ: Princeton University Press.

Shapiro, Ian, and Don Green. 1994. The Pathologies of Rational Choice. New Haven, CT: Yale University Press.

Sher, Victor M., and Andy Stahl. 1990. "Spotted Owls, Ancient Forests, Courts and Congress: An Overview of Citizens' Efforts to Protect Old-Growth Forests and the Species That Live in Them." Northwest Environmental Law Journal 6(2): 361-84.

Simon, Herbert A. 1955. "A Behavioral Model of Rational Choice." Quarterly Journal of Economics 69(1): 99-118.

Simpson, Ralph David. 2005. Conserving Biodiversity through Markets: A Better Approach. PERC. (https:// www.perc.org/wp-content/uploads/old/ps32.pdf).

Sinden, Amy, Douglas A. Kysar, and David M. Driesen. 2009. "Cost-Benefit Analysis: New Foundations on Shifting Sand.” Regulation \& Governance 3(1): 48-71.

Skocpol, Theda. 2013. "Naming the Problem: What It Will Take to Counter Extremism and Engage Americans in the Fight against Global Warming." Presented at Symposium on The Politics of America's Fight Against Global Warming, Harvard University, February 14.

Skogen, Ketil. 2015. "The Persistence of an Economic Paradigm: Unintended Consequences in Norwegian Wolf Management." Human Dimensions of Wildlife 20(4): 317-22.

Somanathan, Eswaran, Raghavan Prabhakar, and Bhupendra Singh Mehta. 2009. "Decentralization for Cost-Effective Conservation." Proceedings of the National Academy of Sciences 106(11): 4143-47.

Speth, James Gustave. 2004. Red Sky at Morning: America and the Crisis of the Global Environment. New Haven, CT: Yale University Press.

Spies, Thomas A., Peter A. Stine, Rebecca A. Gravenmier, Jonathan W. Long, and Matthew J. Reilly. 2018. "Synthesis of Science to Inform Land Management within the Northwest Forest Plan Area." In General Technical Report. PNW-GTR-966. Portland, OR: U.S. 
Department of Agriculture, Forest Service, Pacific Northwest Research Station.

Sprinz, Detlef F. 2009. "Long-Term Environmental Policy: Definition, Knowledge, Future Research." Global Environmental Politics 9(3): 1-8.

Starik, Mark. 1995. "Should Trees Have Managerial Standing? Toward Stakeholder Status for NonHuman Nature." Journal of Business Ethics 14(3): 207-17.

Stavins, Robert N. 1995. "Transaction Costs and Tradeable Permits." Journal of Environmental Economics and Management 29(2): 133-148.

Taylor, Bob Pepperman. 1992. Our Limits Transgressed. 2nd ed. New York: University Press of Kansas.

Thomas, Chris D., Alison Cameron, Rhys E. Green, Michel Bakkenes, Linda J. Beaumont, Yvonne C. Collingham, Barend F.N. Erasmus, et al. 2004. "Extinction Risk from Climate Change." Nature 427: 145-48.

Thomas, Vinod, and Namrata Chindarkar. 2019. Economic Evaluation of Sustainable Development. New York: Palgrave Macmillan.

Tobin, Paul. 2020. "Economics from Zero-Sum to WinWin." Nature Climate Change 10: 386-87.

Tribe, Laurence H. 1972. "Policy Science: Analysis or Ideology?" Philosophy \& Public Affairs 2(1): 66-110.

Turner, R. Kerry, Jouni Paavola, Philip Cooper, Stephen Farber, Valma Jessamy, and Stavros Georgiou. 2003. "Valuing Nature: Lessons Learned and Future Research Directions." Ecological Economics 46(3): 493-510.

UN Environment Programme. 2020a. "Pavan Sukhdev Wins 2020 Tyler Prize for Environmental Achievement." January 27.

_. 2020b. "The UN Environment Programme and Nature-Based Solutions." Published to coincide with the 75th session of the UN General Assembly Our positions. (https://www.unep.org/unga/our-position/ unep-and-nature-based-solutions).

van der Ven, Hamish, Catherine Rothacker, and Benjamin Cashore. 2018. "Do Eco-Labels Prevent Deforestation? Lessons from Non-State Market Driven Governance in the Soy, Palm Oil, and Cocoa Sectors." Global Environment Change 52: 141-51.

Victor, David. 2015. "Why Paris Worked: A Different Approach to Climate Diplomacy." Yale Environment 360, December 15. (https://e360.yale.edu/features/ why_paris_worked_a_different_approach_to_ climate_diplomacy).

Vittersø, Joar, Bjørn P. Kaltenborn, and Tore Bjerke. 1998. "Attachment to Livestock and Attitudes toward Large Carnivores among Sheep Farmers in Norway." Anthrozoös 11(4): 210-17.

Voigt, Maria, Serge A. Wich, Marc Ancrenaz, Jessie Wells, Kerrie A. Wilson, and Hjalmar S. Kuhl. 2018. "Global Demand for Natural Resources Eliminated More Than
100,000 Bornean Orangutans." Current Biology 28(5): 761-69.

Wang, Sen. 2004. "One Hundred Faces of Sustainable Forest Management." Forest Policy and Economics 6(3-4): 205-13.

Webster, Mort. 2008. "Incorporating Path Dependency into Decision-Analytic Methods: An Application to Global Climate-Change Policy." Decision Analysis 5(2): 60-75.

Weimer, David L., and Aidan R. Vining. 1992. Policy Analysis: Concepts and Practice. 2nd ed. Hoboken, NJ: Prentice Hall.

Wendt, Alexander E. 1987. "The Agent-Structure Problem in International Relations Theory." International Organization 41(3): 335-70.

Wijedasa, Lahiru S., Jyrki Jauhiainen, Mari Könönen, Maija Lampela, Harri Vasander, Marie-Claire Leblanc, Stephanie Evers, et al. 2017. "Denial of Long-Term Issues with Agriculture on Tropical Peatlands Will Have Devastating Consequences." Global Change Biology 23(3): 977-82.

Winkler, Ralph. 2006. "Does 'Better' Discounting Lead to 'Worse' Outcomes in Long-Run Decisions? The Dilemma of Hyperbolic Discounting." Ecological Economics 57(4): 573-82.

Wondolleck, Julia M. 1988. Public Lands Conflict and Resolution: Managing National Forest Disputes. Ed. L. Susskind. New York: Plenum Press.

World Bank. World Bank Open Data [Online data]. The World Bank 2020. February 16. (https:// data.worldbank.org/).

WRI. Forest Pulse: The Latest on the World's Forests. World Resources Institute 2020. (https://research.wri.org/gfr/ forest-pulse).

Wright, Glenn D., Krister P. Andersson, Clark C. Gibson, and Tom P. Evans. 2016.

"Decentralization Can Help Reduce Deforestation when User Groups Engage with Local Government." Proceedings of the National Academy of Sciences 113(52): 14958-63.

Yaffee, Steven Lewis. 1994. The Wisdom of the Spotted Owl: Policy Lessons for a New Century. Covelo, CA: Island Press.

Young, Oran R. 2003a. "Determining Regime Effectiveness: A Commentary on the Oslo-Potsdam Solution." Global Environmental Politics 3(3): 97-104.

— . 2003b. "Environmental Governance: The Role of Institution in Causing and Confronting Environmental Problems." International Environmental Agreements 4(4): 377-93.

Zeckhauser, Richard, and Elmer Schaefer. 1968. "Public Policy and Normative Economic Theory." In The Study of Policy Formation, ed. R.A. Bauer and K.J. Gergen, 27-102. New York: Free Press. 